\title{
TEST PAMĚTI A UČENÍ - DRUHÉ VYDÁNí (TOMAL-2) Recenze metody
}

\author{
AUTOŘI RECENZE: JANA FIKRLOVÁ ${ }^{1}$
}

\begin{tabular}{|l|l|}
\hline Datum vzniku recenze & 1.12 .2019 \\
\hline Název nástroje & Test paměti a učení - Druhé vydání \\
\hline Zkrácený název & TOMAL-2 \\
\hline Původní název & Test of Memory and Learning - Second Edition \\
\hline Autoři původního testu & Cecil R. Reynolds, Judith K. Voress \\
\hline Autoři lokální adaptace & $\begin{array}{l}\text { Jiří Laciga, Daniel Dostál, Dagmar Brejlová, Miroslav } \\
\text { Zárecký, Adéla Rajsiglová }\end{array}$ \\
\hline Lokální distributor & Propsyco, s.r.o. \\
\hline Datum vydání & 2017 \\
\hline
\end{tabular}

Test paměti a učení - Druhé vydání (dále TOMAL-2) představuje komplexní testovou baterii pro posuzování pamět'ových schopností, která je určena pro populaci ve věku od 5 do 59 let. TOMAL-2 se soustředí primárně na posouzení celkové, verbální a neverbální paměti (Propsyco, 2017). Důraz byl kladen na minimalizaci možnosti verbální mediace při plnění neverbálních subtestů (Adams \& Reynolds, 2009) Doplňkové subtesty cílí na posouzení specifických aspektů paměti, jakými jsou například verbální oddálené vybavení či prostorová pamět'. Dále umožňují oddělené posouzení paměti, pozornosti jako nutného předpokladu pro zapamatování informací a učení, které je s pamětí úzce spjato (Propsyco, 2017). Žádný ze subtestů nevyžaduje použití grafomotorických schopností (Adams \& Reynolds, 2009).

Základní baterie sestává z 8 subtestů určených jak k posouzení celkového skóru paměti, tak k posouzení verbální a neverbální paměti. Na verbální pamět’ se zaměřují 4 základní subtesty (Pamět' na příběhy, Pamět' na slova, Pamět' na předměty a Pamět' na dvojice slov), které společně tvoří kompozitní Index verbální paměti. Na neverbální pamět' cílí rovněž 4 základní subtesty (Pamět' na tváře, Abstraktní vizuální pamět', Vizuální sekvenční pamět' a Pamět' na umístění), které utváří kompozitní Index neverbální paměti. Celková pamět' je hodnocena na základě kombinace všech 8 základních subtestů, které

\footnotetext{
${ }^{1}$ Katedra psychologie, Fakulta sociálních studií MU, Joštova 10, 60200 Brno
} 
poskytují Kompozitní index paměti. Základní baterii rozšiřuje 6 doplňkových subtestů, a to 4 verbální (Opakování čísel dopředu, Opakování písmen dopředu, Opakování čísel pozpátku a Opakování písmen pozpátku) a 2 neverbální (Vizuální selektivní pamět’ a Manuální imitace). Na základě doplňkových subtestů lze vyvodit další kompozitní indexy, a to Index pozornosti/soustředění, Index sekvenčního vybavení, Index volného vybavení, Index asociačního vybavení a Index učení. Poslední kompozitní index, Index verbálního oddáleného vybavení, je získán na základě oddáleného vybavení základních subtestů Pamět' na príiběhy a Pamět' na slova (Propsyco, 2017).

Původní, americkou verzi TOMAL-2 vytvořili Reynolds a Voress (2007) - jedná se o revizi pamětového testu Test of Memory and Learning (dále TOMAL), který byl určen pro děti a dospívající ve věkovém rozmezí od 5 do 19 let (Reynolds \& Bigler, 1994). Reynolds a Voress (2007) provedli několik zásadních změn. V první řadě představuje TOMAL-2 rozšiřrení testu na dospělou populaci. Byly vyřazeny některé nevyhovující položky. Nejdelší subtest, Vizuální selektivní pamět', byl přesunut do doplňkových subtestů. Pro nízkou reliabilitu byly vyřazeny subtesty na oddálené neverbální vybavení. Došlo k úpravě kritérií pro bazální úroveň a strop. Zároveň je nutné zdůraznit, že všechny položky TOMAL-2 vychází z původního TOMAL. Zásadní je také informace, že 1382 osob z celkového počtu 1961 osob, které tvoří americký standardizační vzorek TOMAL-2, pochází z původního sběru dat pro standardizaci TOMAL (Propsyco, 2017). Tyto informace jsou důležité zejména proto, že český manuál přebírá z amerického manuálu některé validizační studie a studie reliability provedené s použitím testu TOMAL.

Reynolds a Voress (2012) vytvořili také seniorskou verzi TOMAL-SE (Test of Memory and Learning-Senior Edition), která byla normována pro dospělé ve věkovém rozpětí od 55 do 89 let. V České republice právě probíhá standardizace této verze (Katedra psychologie FSS, 2019).

TOMAL-2 lze využít v oblasti klinické psychologie a neuropsychologie (např. u epilepsie, traumatických poranění mozku či demence), a to jak u dětí (především u poruch učení či poruch pozornosti), tak u dospělých (Propsyco, 2019).

\section{Administrace a skórování}

TOMAL-2 je administrován individuálně formou tužka-papír. Administrace základní baterie trvá 30-35 minut. Administrace všech doplňkových subtestů zabere dalších 2535 minut. TOMAL-2 spadá do kategorie $\mathrm{C}$, což znamená, že metodu je oprávněn používat pouze absolvent magisterského studia psychologie. Nad rámec tohoto základního požadavku autoři doporučují provedení několika cvičných administrací s tím, že prvních 3 až 5 může zabrat 60-75 minut (Propsyco, 2017). Společnost Propsyco zájemcům také nabízí kurzy odborného zaškolení do práce s TOMAL-2 (Propsyco, 2019).

Všechny důležité pokyny k zadávání jednotlivých subtestů, prostor pro zaznamenání odpovědí a prostor pro součet hrubých skórů jsou k dispozici v Záznamové př́ručce. Vyhodnocení je možné jak ručně s pomocí kvalitně zpracovaného Profilového listu a 
tabulek norem, reliabilit a standardních chyb měření, tak on-line. On-line vyhodnocení je uživatelsky př́ivětivé, rychlé a součástí výstupu jsou navíc intervaly spolehlivosti nejen pro standardní skóry, ale v př́ípadě kompozitních indexů také pro percentily.

Metoda pracuje s několika druhy skórů. Hrubé skóry subtestů, které představují součet bodů získaných v subtestu, se převádí na standardní skóry subtestů $(M=10, S D=3)$. Standardní skóry indexů jsou získány součtem standardních skórů odpovídajících subtestů a jejich převodem $(M=100, S D=15)$. Pro standardní skóry subtestů i pro standardní skóry indexů jsou navíc ve stejných tabulkách uvedeny také percentily. V př́lohách má uživatel dále $\mathrm{k}$ dispozici tabulky pro převod standardních skórů subtestů a standardních skórů indexů na T-skóry, z-skóry, staniny, ekvivalenty normálního rozložení a věkové ekvivalenty, přičemž autoři upozorňují na nevýhody věkových ekvivalentů. Ruční i on-line vyhodnocení umožňují zakreslení křivky učení klienta na základě subtestů, u kterých dochází k opakované prezentaci podnětů, a její srovnání s průměrnými hodnotami věkové skupiny klienta. Dopočítat lze také statistickou významnost rozdílu mezi základními kompozitními indexy.

\section{Normy}

Česká standardizační studie byla provedena na vzorku 925 osob ve věku 5 let až 59 let a 11 měsíců. Standardizační soubor byl rozdělen do 24 věkových skupin - od 5 do 10 let byla každá skupina rozdělena po půl roce, od 10 do 20 let po jednom roce a nad 20 let po 10 letech. Autoři testu se snažili zajistit reprezentativní vzorek, a to s využitím informací o demografických charakteristikách české populace ze Sčítání lidu, domů a bytů v roce 2011. Soubor se autoři snažili vyvážit z hlediska počtu mužů a žen, velikosti bydliště, nejvyššího dosaženého vzdělání v případě dospělých a nejvyššího dosaženého vzdělání rodičů a typu školy v př́padě dětí a adolescentů. Zastoupení v jednotlivých kategoriích odpovídá očekávaným procentům výskytu $\mathrm{v}$ populaci kromě nejvyššího dosaženého vzdělání v kategoriích dospělých respondentů. Podařilo se dodržet zastoupení osob s maturitou a s výučním listem, ale v případě osob s vysokoškolským vzděláním a osob se základním vzděláním došlo $\mathrm{k}$ mírnému odchýlení. Zatímco $\mathrm{v}$ populaci se podíl vysokoškoláků $\mathrm{v}$ jednotlivých věkových skupinách pohyboval mezi 12 až $23 \%$, ve standardizačním souboru se pohyboval mezi 20 až 27 \%. Podíl osob se základním vzděláním v jednotlivých věkových skupinách se v populaci pohyboval mezi 10 až $17 \%$ a ve standardizačním souboru pak mezi 3 až 10 \%. Standardizační soubor lze považovat za o něco vzdělanější, než by odpovídalo populaci, avšak odchylka je jen malá (Propsyco, 2017).

Vzorek 925 se jeví jako velký, ale je důležité zdůraznit, že do jednotlivých věkových kategorií je zařazeno 74 až 183 osob. Autoři americké verze testu stejný problém adresovali použitím průběžného postupu podle Roida (continuous norming procedure), který při odhadu percentilových norem a norem standardních skórů pracuje $s$ vyhlazením hodnot průměru, rozptylu, šikmosti a špičatosti v každé věkové skupině. $\mathrm{V}$ př́padě české verze autoři použili komplexnější postup $\mathrm{k}$ vyhlazování, který podrobně 
dokumentují v manuálu. Rozhodli se zohlednit fakt, že tvary rozložení hrubých skórů jsou v př́padě TOMAL-2 velmi různorodé a redukce informací na zmíněné 4 statistiky podle nich dostatečně nezachycuje skutečné chování hrubého skóru. Zohledněn byl také požadavek na to, aby standardní skóry odpovídaly vývojové křivce kognitivních schopností (Propsyco, 2017). Velikost vzorku v jednotlivých věkových skupinách lze ve výsledku považovat za velmi dobrou (Iliescu, 2017). I přes odlišné postupy jsou výsledky české a americké standardizace velmi podobné.

Pro uživatele testu je důležité zmínit také určité problémy s efektem stropu a problémy $\mathrm{s}$ efektem podlahy v určitých věkových skupinách. Efekt stropu se týká především věkové skupiny 20 až 29 let, kdy jsou pamětové schopnosti z vývojového hlediska na vrcholu. Například v případě subtestu Pamět' na dvojice slov odpovídá dosažení maximálního počtu bodů v hrubém skóru 84 . percentilu a standardnímu skóru 13. Žádný dospělý ve věku 20 až 29 let tak nemůže v tomto subtestu dosáhnout vyššího percentilu než 84 . Efekt podlahy je pak patrný především v mladších věkových skupinách. Ve věkové skupině od 5 let do 5 let a 5 měsíců dítě například v subtestu Pamět' na příběhy nemůže získat nižší standardní skór než 5, který odpovídá 5. percentilu.

\section{Validita}

Česká verze manuálu se nadstandardně kvalitně věnuje posouzení konstruktové validity pomocí faktorové analýzy. $V$ tomto ohledu dokonce dalece překračuje úroveň americké verze. $V$ americké verzi byl zvolen explorační př́stup - byla použita metoda hlavních faktorů (principal factor analysis, $P F A$ ) se šikmou rotací Promax na americkém standardizačním vzorku. Finální čtyřfaktorové řešení, které dosáhlo dobré shody modelu s daty, tvoří faktor všeobecné paměti, faktor prostorové paměti, faktor sekvenčního vybavení dopředu a faktor sekvenčního vybavení pozpátku (Reynolds \& Voress, 2007). Tento postup je však problematický - autoři zvolili explorační př́stup i přes to, že měli na základě teorie hypotézy o konstruktu. Vhodnější by bylo použít přístup konfirmační. Autoři české verze nejprve použili stejný postup jako autoři americké verze s tím, že na základě koeficientů kongruence usoudili, že faktorová struktura české verze je velmi podobná faktorové struktuře americké verze. Následně provedli konfirmační faktorovou analýzu - finální bifaktorové řešení dosáhlo vynikající shody modelu s daty a předkládá faktor kompozitní paměti, který sytí každý z 8 základních subtestů, faktor verbální paměti sytící verbální subtesty a faktor neverbální paměti sytící neverbální subtesty. Autoři rovněž vypočetli hierarchickou McDonaldovu omegu, která dosáhla hodnoty 0,72, a celkovou McDonaldovu omegu, která dosáhla hodnoty 0,85 . Na základě těchto výsledků vyvozují, že bifaktorový model vysvětlil $85 \%$ rozptylu vážených skórů základních subtestů, přičemž $72 \%$ tohoto rozptylu vysvětluje obecný, kompozitní faktor paměti a $13 \%$ vysvětlují faktor verbální paměti a faktor neverbální paměti. Zjištění interpretují jako silnou podporu pro existenci všeobecného faktoru paměti (Propsyco, 2017).

Předpoklad, že pamět' podobně jako další kognitivní schopnosti závisí na věku, přičemž v průběhu dětství strmě stoupá, na počátku dospělosti dosahuje svého maxima a poté 
velmi pozvolně klesá, ověřovali autoři české verze pomocí vývojových křivek s využitím dat celého standardizačního souboru. Průběh vývojových křivek odpovídal očekávání (Propsyco, 2017).

Ke kriteriální validitě autoři přistoupili na základě předpokladu, že pamět'ové schopnosti a schopnost učit se úzce souvisí s tím, jakého vzdělání člověk dosáhne. Zjišt’ovali souvislost mezi výsledky v TOMAL-2 a dosaženým vzděláním. Použili údaje respondentů starších 20 let ze standardizačního souboru $(\mathrm{N}=271)$. Do regresní analýzy nejprve zařadili pohlaví a věk, které společně vysvětlily 18 \% rozptylu výsledků v TOMAL-2. Přidáním proměnné vzdělání vzrostl podíl vysvětleného rozptylu o $32 \%\left(\Delta \mathrm{R}^{2}=0,32\right)$. V př́padě respondentů do 20 let ze standardizačního souboru $(\mathrm{N}=653)$ zkoumali vztah mezi výsledky v TOMAL-2 a vzděláním rodičů. Pohlaví a věk vysvětlily $11 \%$ rozptylu výsledků v TOMAL-2. Zařazení vzdělání rodičů do modelu vedlo k nárůstu o dalších 13 $\%\left(\Delta \mathrm{R}^{2}=0,13\right)$. Podle autorů tyto výsledky naznačují, že by TOMAL-2 mohl být použit k odhadnutí budoucího vzdělání či školní úspěšnosti (Propsyco, 2017). Důkazy o prediktivní validitě ovšem nepředkládají. Zároveň považuji za důležité upozornit na to, že nebyl kontrolován socioekonomický status, který se školními výsledky souvisí (např., Česká školní inspekce, 2014).

Další důkazy o kriteriální validitě přejímají autoři české adaptace z amerického manuálu. Souběžnou validitu s ostatními nástroji měřícími pamět' demonstrují autoři americké verze na dvou studiích. Jedna pochází z americké standardizace pamětového testu WRAML-2 (Wide Range Assessment of Memory and Learning). Srovnává WRAML-2 s první verzí TOMAL, přičemž vzorek tvořili děti a adolescenti (Sheslow \& Adams, 2003). Druhá pochází z americké standardizace TOMAL-2 a vzorek tvořili dospělí (Reynolds \& Voress, 2007). Sílu zjištěných korelací lze považovat za velmi dobrou $(r=0,69-0,79)$. Ve prospěch TOMAL-2 hovoří také středně silné až silné korelace s inteligenčními testy a s výkonovými testy ( $r=0,40-0,65$; Reynolds \& Voress, 2007), které naznačují, že test s inteligencí a s výkonem souvisí, ale zároveň má vůči inteligenčním a výkonovým testům inkrementální validitu (Propsyco, 2017). Podobné vzorce korelací se vyskytují i u WRAML-2 (Sheslow \& Adams, 2003).

Určitou výhradu mám vůči způsobu, jakým jsou důkazy o validitě $v$ manuálu prezentovány. Není zcela jednoduché odlišit důkazy z americké standardizace od důkazů z české standardizace. $V$ př́ípadě americké standardizace navíc pochází řada důkazů ze studií, ve kterých autoři použili první verzi TOMAL. To lze do určité míry ospravedlnit, nebot' TOMAL-2 obsahuje stejné položky jako TOMAL a standardizační vzorek TOMAL2 zahrnuje původní standardizační vzorek TOMAL (Reynolds \& Voress, 2007). TOMAL byl ovšem standardizován pouze pro věk 5 až 19 let (Reynolds \& Bigler, 1994), a tak validizační studie pokrývají pouze tuto skupinu. Dalším problémem je to, že ačkoliv lze výsledky TOMAL generalizovat na TOMAL-2 (Schmitt \& Decker, 2008), při standardizaci TOMAL v 90. letech byly použity testy inteligence či výkonu, které už také prošly revizí jako např. WISC-R (Dehn, 2010; Schmitt \& Decker, 2008). 
Informace o obsahové validitě ve smyslu reprezentativního výběru položek z domény přebírají autoři české verze testu z amerického manuálu. Položky TOMAL-2 byly vybrány z položkové banky původního TOMAL. Tvorba položek pro TOMAL vycházela z klinických zkušeností autorů, ze studia teoretických a empirických poznatků o paměti a dostupných pamětových testů. Položky byly konzultovány s experty na konstrukt (subject matter experts, SMEs), kteří posuzovali, jaké kognitivní funkce jednotlivé subtesty měří. Každý subtest byl podroben pilotnímu testování, jehož výsledky podnítily změny v administraci i testovém materiálu. Po jakékoliv změně bylo provedeno nové zkušební testování (Reynolds \& Voress, 007). Podrobnější analýza položek a dokumentace jejich vývoje by měly být dostupné v manuálu první verze TOMAL (Adams \& Reynolds, 2009), kterou však nemá běžný český uživatel k dispozici. Autoři české adaptace bohužel nekomentují ani překlad a adaptaci položek a testových instrukcí do češtiny.

$\mathrm{Z}$ amerického manuálu jsou převzaty také informace o férovosti. Konkrétně bylo testováno zkreslení položek na základě pohlaví a na základě etnické příslušnosti. Použit byl Jensenův delta scores approach. Výsledky v podobě vysokých korelací (u všech položek vyšší než 0,9$)$ mezi hodnotami delta naznačují vysokou podobnost fungování položek napříč skupinami (Hartman, 2007; McCallum, 2003). Považuji ale za důležité podotknout, že diferenciální fungování položek bylo testováno pouze u původního standardizačního souboru TOMAL na počátku 90. let (Reynolds \& Bigler, 1994). Na základě výsledků nelze usuzovat na nezkreslenost položek v českém standardizačním souboru, což se v českém manuálu do určité míry děje. Autoři české verze na základě těchto údajů usuzují, že se povedlo dosáhnout stejného fungování položek pro muže i pro ženy a diskutují potenciální skutečné rozdíly v pamět'ových schopnostech mezi pohlavími v České republice (Propsyco, 2017).

Vzhledem k tomu, že TOMAL a TOMAL-2 byly navrženy s důrazem na to, aby se jednalo o užitečné nástroje pro provádění klinického posouzení, lze předpokládat senzitivitu TOMAL-2 na neurologické poruchy, poruchy pozornosti s hyperaktivitou, traumatické poranění mozku či poruchy učení. Prvotní verze TOMAL se ukázala jako senzitivní na poruchy učení (Howes a kol., 1999) i na traumatické poranění mozku (Lowther \& Mayfield, 2004). Za pozornost stojí také novější studie. Např́íklad výsledky studie Thalera a kolegů (2010) podpořily vhodnost TOMAL pro posuzování neuro-kognitivních deficitů u dětí s ADHD. Thaler a kolegové (2011) nalezli další podporu pro senzitivitu TOMAL na traumatické poranění mozku.

\section{Reliabilita}

Autoři české adaptace poskytují odhady reliability ve smyslu vnitřní konzistence a odhady standardní chyby měření získané na českém standardizačním vzorku pro všechny dílčí subtesty i kompozitní indexy, a to např́ič 8 věkovými skupinami. Reliability dosahují excelentních hodnot. Reliabilita Kompozitního indexu paměti neklesla v žádné věkové skupině pod 0,95 . $\mathrm{V}$ př́padě Indexů verbální paměti a Indexů neverbální paměti neklesla pod 0,94. Mediány reliabilit všech základních indexů se pohybovaly v rozmezí 
0,94-0,97. V př́padě doplňkových indexů se mediány reliabilit pohybovaly v rozmezí 0,91-0,97 s výjimkou Indexu verbálního oddáleného vybavení, u kterého dosáhl medián hodnoty 0,85 . Mediány reliabilit napříč věkovými skupinami se u většiny základních i doplňkových subtestů pohybovaly v rozmezí 0,85-0,97. Výjimku tvoří pamět' na tváře $(0,80)$, vizuální sekvenční pamět' $(0,80)$ a oddálená pamět' na slova $(0,70)$ (Propsyco, 2017).

Autoři české verze kritizují, že při americké standardizaci byla reliabilita subtestů odhadována pomocí Cronbachovy alfy (Propsyco, 2017). Tato výtka je opodstatněná vzhledem k př́ísnému předpokladu Cronbachovy alfy, kterým je tau-ekvivalence položek, přičemž nedodržení tohoto předpokladu vede $\mathrm{k}$ podhodnocení skutečné reliability. Namísto toho se autoři české adaptace rozhodli použít split-half reliabilitu spolu s korekcí pomocí Spearmanova-Brownova věšteckého vzorce, a to jak pro odhad reliabilit subtestů, tak pro odhad reliabilit kompozitních skórů. Autoři také položky každého subtestu seřadili podle jejich rozptylu a až poté je rozdělili na sudé a liché (Propsyco, 2017), pravděpodobně za účelem dosažení co nejpodobnějšího rozptylu obou polovin testu. Striktním předpokladem tohoto postupu jsou paralelní položky - při jeho nedodržení může být Spearmanův-Brownův věštecký vzorec př́liš optimistický a reliabilitu nadhodnotit. Pro odhad vnitřní konzistence subtestů by bylo vhodnější použít McDonaldovu omegu, která nevyžaduje tau-ekvivalenci, a pro odhad vnitřní konzistence kompozitních indexů například stratifikovanou Cronbachovu alfu, která by zohlednila vícedimenzionalitu těchto indexů. Nadstandardní je použití hierarchické McDonaldovy omegy $(\omega=0,72)$ a celkové McDonaldovy omegy $(\omega=0,85)$ pro odhad reliability konstruktu a posouzení významu faktorů v bifaktorovém modelu. Autoři české adaptace rovněž upozorňují na to, že obeznámenost s různými koeficienty omega $(\omega)$ nepatří mezi běžné znalosti uživatelů testů (Propsyco, 2017). To mohlo přispět i k rozhodnutí autorů zvolit pro odhad reliabilit subtestů a indexů známější a více zaužívanou split-half reliabilitu, a to i přes její nevýhody.

Na rozdíl od americké standardizace autoři neposkytují údaje o reliabilitě test-retest ani o shodě posuzovatelů. Informace přebírají z amerického manuálu (Propsyco, 2017). Reliabilita test-retest byla $\mathrm{v}$ americké verzi přijatelná (u základních indexů v rozmezí $0,71-0,94$, u doplňkových $0,68-0,94)$, ale byla ověřována na malých vzorcích $(\mathrm{N}=35-$ 47). Shoda posuzovatelů byla v americké verzi velmi dobrá $(0,94$ nebo vyšší).

\section{Shrnutí}

Velkou předností TOMAL-2 jsou kvalitní české normy pro 24 věkových skupin, přičemž menší počet respondentů $\mathrm{v}$ jednotlivých věkových kategoriích autoři české adaptace adekvátně vyřešili pomocí vyhlazování. Při tvorbě norem také zohlednili různorodost rozložení hrubých skórů subtestů TOMAL-2 a vývojovou křivku kognitivních schopností. Při interpretaci by uživatelé měli mít na paměti efekty stropu ve věkové skupině od 20 do 29 let a efekty podlahy přítomné u nejmladších věkových skupin. 
Dalším kladem české adaptace je posouzení konstruktové validity pomocí konfirmační faktorové analýzy, jejíž provedení je nadstandardně kvalitní. Ověření konstruktové validity české adaptace TOMAL-2 je tak dokonce na vyšší úrovni než ověření konstruktové validity americké verze testu. Z hlediska kriteriální validity autoři české adaptace provedli studii zaměřenou na vztah mezi TOMAL-2 a dosaženým vzděláním v př́padě dospělých a studii zaměřenou na vztah mezi TOMAL-2 a dosaženým vzděláním rodičů $v$ prŕípadě dětí a adolescentů. Důkazy o souběžné validitě $s$ jinými testy přebírají $\mathrm{z}$ americké verze manuálu. Žádoucí by bylo provést další validizační studie, které by srovnaly výsledky v TOMAL-2 s výsledky v současné době používaných inteligenčních, výkonových a pamětových testů. Pro účely české adaptace by bylo ideální posoudit souběžnou validitu TOMAL-2 s jinými testy používanými v České republice, a to např́klad s Wechslerovou pamět'ovou škálou WMS-III (Wechsler, 1999) nebo s Wechslerovou zkrácenou pamět’ovou škálou WMS-IIIa (Wechsler, 2011). Užitečná by byla také konormace TOMAL-2 s inteligenčními testy (např. Woodcock-Johnson IV). Konormace inteligenčních a pamětových testů umožňuje identifikovat diskrepance mezi inteligenčním a pamět’ovým výkonem, což je významné pro identifikaci organických a kognitivních poruch (Drozdick a kol., 2011). Pozitivním vývojem je, že v současnosti probíhá konormace seniorské verze Testu paměti a učení TOMAL-SE s Testy školních dovedností (BACH), což umožní diagnostiku kognitivních poruch a organických poškození mozku u seniorské populace (Katedra psychologie FSS, 2019). Souhrnně lze validitu TOMAL-2 považovat za velmi dobrou.

Ocenění hodné je také to, že autoři české verze testu poskytují odhady reliability ve smyslu vnitřní konzistence a odhady standardní chyby měření pro všechny subtesty a všechny kompozitní indexy, a to zvlášt’ pro 8 věkových skupin. Reliability navíc dosahují vynikajících hodnot, a to jak u kompozitních indexů, tak u jednotlivých subtestů. Mimořádně chvályhodné je, že autoři české adaptace přistoupili k odhadu reliability konstruktu pomocí hierarchické McDonaldovy omegy a celkové McDonaldovy omegy. Reliabilitu test-retest autoři české adaptace nezkoumali a přebírají ji z americké verze manuálu, což lze ovšem považovat za dostačující. Reliabilita české adaptace TOMAL-2 je celkově na vysoké úrovni.

Výborné je také zpracování podnětových materiálů a uživatelsky nesmírně přívětivé ruční i on-line vyhodnocení TOMAL-2. Pozitivním aspektem podnětových materiálů je také to, že na rozdíl od Reyovy-Osterriethovy komplexní figury nebo Bentonova vizuálního retenčního testu nevyžadují zapojení grafomotorických schopností. Porucha percepčně motorické oblasti může totiž ovlivnit grafomotorické schopnosti a v důsledku i pamět’ový výkon v těchto dvou testech (Adams \& Reynolds, 2009). Dobře zpracován je také manuál k české verzi, který obsahuje minimum terminologických nesrovnalostí či překlepů.

Celkově TOMAL-2 představuje kvalitní nástroj pro posouzení paměti. Psychometrické zpracování české adaptace je vysoce nadprůměrné a příkladné. Přímý konkurent TOMAL-2 na českém trhu, Wechslerova pamět'ová škála WMS-III, disponuje pouze 
americkými, a navíc zastaralými normami (Wechlser, 1999). Její kratší verze, Wechslerova zkrácená pamět'ová škála WMS-IIIa (2011), sice české normy má, ale jejich kvalita je bohužel nízká (podrobněji viz Hlavová \& Rosická, 2018). WMS-IIIa navíc představuje spíše screeningový nástroj, který nemůže nahradit komplexnější vyšetření paměti (Mitrushina a kol., 2005). Česká adaptace Wechslerovy pamět’ové škály WMS-IV, která je revizí WMS-III a řeší řadu jejích omezení (viz Groth-Marnat \& Wright, 2016), se momentálně nepřipravuje (S. Ježek, osobní komunikace, 14. října 2019). Domnívám se, že TOMAL-2 lze doporučit jako momentálně nejkvalitnější test paměti na českém trhu, a to pro použití v oblasti neuropsychologie a v oblastech klinické, školní a poradenské psychologie.

\section{Zdroje}

Adams, W., \& Reynolds, C. R. (2009). Essentials of WRAML2 and TOMAL-2 Assessment. John Wiley \& Sons.

Česká školní inspekce. (2014). Sekundární analýzy výsledků šetření PISA 2012. https://www.csicr.cz/Csicr/media/Prilohy/PDF el. publikace/Mezin\%C3\%A1rodn\%C 3\%AD\%20\%C5\%A1et\%C5\%99en\%C3\%AD/PISA 2012 SA.pdf

Dehn, M. J. (2010). Long-term memory problems in children and adolescents: Assessment, intervention, and effective instruction. John Wiley \& Sons.

Drozdick, L. W., Holdnack, J. A., \& Hilsabeck, R. C. (2011). Essentials of WMS-IV Assessment. John Wiley \& Sons.

Groth-Marnat, G., \& Wright, J. A. (2016). Handbook of psychological assessment (6th ed.). John Wiley \& Sons.

Hartman, D. (2007). TEST REVIEW: PSST! Wanna buy a good new memory test-cheap?: The Test of Memory and Learning-2. Applied Neuropsychology, 14(4), 307-309. https://doi.org/10.1080/09084280701719443

Hlavová, R., \& Rosická, A. M. (2018). Wechslerova zkrácená pamět’ová škála: Recenze metody. Testfórum, 11, 43-48. http://doi.org/10.5817/tf2018-11-203

Howes, N. L., Bigler, E. D., Lawson, J. S., \& Burlingame, G. M. (1999). Reading disability subtypes and the test of memory and learning. Archives of Clinical Neuropsychology: The Official Journal of The National Academy of Neuropsychologists, 14(3), 317-339. http://search.ebscohost.com/login.aspx?direct=true\&db=mdc\&AN=14590599\&lang=cs

Iliescu, D. (2017). Adapting tests in linguistic and cultural situations. Cambridge University Press.

Katedra psychologie FSS. (2019). Nabídka práce: Standardizace Testů školních dovedností (BACH). https://psych.fss.muni.cz/cosedeje/aktuality/nabidka-pracestandardizace-testu-skolnich-dovednosti-bach 
Lowther, J. L., \& Mayfield, J. (2004). Memory functioning in children with traumatic brain injuries: a TOMAL validity study. Archives of Clinical Neuropsychology: The Official Journal of The National Academy of Neuropsychologists, 19(1), 105-118. http://search.ebscohost.com/login.aspx? direct=true \&db=mdc\&AN=14670383\&lang=cs

McCallum, R. S. (2003). Handbook of Nonverbal Assessment. Springer Science \& Business Media.

Mitrushina, M., Boone, K. B., Razani, J., \& D'Elia, L. F. (2005). Handbook of normative data for neuropsychological assessment. Oxford University Press.

Propsyco. (2017). Test paměti a učení - Druhé vydání: Příručka. Propsyco, s.r.o.

Propsyco. (2019). Propsyco. https://shop.propsyco.cz/

Reynolds, C. R., \& Bigler, E. (1994). Test of Memory and Learning. PRO-ED.

Reynolds, C. R., \& Voress, J. K. (2007). Test of Memory and Learning: Second Edition. PROED.

Reynolds, C. R., \& Voress, J. K. (2012). TOMAL-SE: Test of memory and learning-senior edition. PRO-ED.

Sheslow, D., \& Adams, W. (2003). Wide Range Assessment of Memory and Learning-Second Edition. Wide Range.

Schmitt, A. J., \& Decker, S. L. (2008). Review of Test of memory and learning: Second edition. Journal of Psychoeducational Assessment, 27(2), 157-166. https://doi.org/10.1177/0734282908322449

Thaler, N. S., Allen, D. N., McMurray, J. C., \& Mayfield, J. (2010). Sensitivity of the Test of Memory and Learning to attention and memory deficits in children with ADHD. The Clinical Neuropsychologist, 24(2), 246-264. https://doi.org/10.1080/13854040903277305

Thaler, N., Barney, S., Reynolds, C., Mayfield, J., \& Allen, D. (2011). Differential sensitivity of TOMAL subtests and index scores to pediatric traumatic brain injury. Applied Neuropsychology, 18(3), 168-178. https://doi.org/10.1080/13854040903277305

Wechsler, D. (1999). Wechslerova pamětová škála WMS-III. Psychodiagnostika.

Wechsler, D. (2011). Wechslerova zkrácená pamětová škála WMS-IIIa. Hogrefe Testcentrum. 


\author{
EFPA \\ STANDING COMMITTEE ON \\ TESTS AND TESTING (SCTT)
}

Příloha ke Zprávě předsedy, 2005

MODEL RECENZE PODLE EFPA PRO POPIS

A HODNOCENÍ PSYCHOLOGICKÝCH TESTŮ

FORMULÁŘ RECENZE TESTU A POZNÁMKY PRO RECENZENTY

Verze 3.42

Lokální úprava pro časopis Testforum

ISSN 1805-9147 


\section{MODEL RECENZE PODLE EFPA PRO POPIS \\ A HODNOCENÍ PSYCHOLOGICKÝCH TESTŮ \\ FORMULÁŘ RECENZE TESTU A POZNÁMKY PRO \\ RECENZENTY ${ }^{1}$}

Toto je lokální úprava dokumentu pro účely publikace v časopise Testfórum.

Originální český překlad je k dispozici na stránkách EFPA

(www.efpa.eu/download/505cd9db4144ecb16174087909c9cd6d).

Původní verzi sestavil a uspořádal Dave Bartram

Doplnili a revidovali Patricia Lindley, Dave Bartram a Natalie Kennedy v dubnu $2004^{2}$

Současná verze 3.42: květen 2005

Český překlad: Tomáš Urbánek

Od uživatelů tohoto dokumentu a jeho obsahu žádá EFPA, aby uznali tento zdroj prostřednictvím následujícího textu:

"Kritéria pro recenzi testu podle EFPA do značné míry vychází z formy a obsahu kritérií pro recenze testů Britské psychologické společnosti (BPS) a kritérií vytvořených Komisí pro testové záležitosti (COTAN) Holandské asociace psychologů (NIP). Dave Bartram a Patricia Lindley původně vyvinuli kritéria BPS a recenzní procedury pro UK Employment Service a později rozšírili jejich používání pro celou BPS. Arne Evers připravil k vydání nizozemský system posuzování kvality testů.

EFPA je vděčná BPS a NIP za svolení použít jejich kritéria jako základ pro vytvoření evropského modelu. EFPA je také vděčná Davu Bartramovi, Arnu Eversovi a Patricii Lindley za jejich přispění $k$ vývoji tohoto modelu. Veškerá intelektuální vlastnická práva původních kritérií podle BPS a NIP jsou nadále uznávána a náleží těmto orgánům."

\footnotetext{
1 Tento dokument byl vytvořen z několika zdrojů, včetně Hodnotícího formuláře pro recenzi testu používaného v BPS (NPAL a Řídící komise pro testové standardy při BPS - Steering Committee on Test Standards), Španělského dotazníku pro hodnocení psychometrických testů (Španělská psychologická asociace) a Systému pro posuzování kvality testu (Komise pro testování Holandské asociace psychologů). Některé části byly adaptovány se svolením z dokumentu: BPS Books Reviews of Level B Assessment Instruments for use in Occupational Assessment, Notes for Reviewers: Version 3.1. December 1998: Copyright (C) NPAL, 1989, 1993, 1998.

2 Současná verze je spojením dvou oddělených dokumentů (Formuláře recenze a Poznámek pro recenzenty). Obsah byl navíc uspořádán a doplněn na základě jeho používání recenzenty online testů v BPS.
} 


\section{Č́st 1:}

Popis nástroje: Obecné informace a klasifikace

\begin{tabular}{|c|c|c|}
\hline \multicolumn{3}{|c|}{ FPA 3.2 reference } \\
\hline & Recenzent 1: & Bc. Jana Fikrlová \\
\hline & Recenzent 2: & \\
\hline & Konzultující editor: & Mgr. Jaroslav Gottfried \\
\hline & Vedoucí editor: & Mgr. Hynek Cígler, Ph.D. \\
\hline & $\begin{array}{l}\text { Vedoucí editor aktualizace: } \\
\text { (pouze v př́padě aktualizací) }\end{array}$ & \\
\hline & $\begin{array}{l}\text { Editor aktualizace: } \\
\text { (pouze v př́padě aktualizací) }\end{array}$ & \\
\hline & Datum vzniku této recenze: & 1. 12. 2019 \\
\hline 1.1 & Název nástroje (lokální verze): & Test paměti a učení - Druhé vydání \\
\hline & Zkrácená verze názvu testu: & TOMAL-2 \\
\hline 1.2 & $\begin{array}{l}\text { Původní název testu (pokud je lokální } \\
\text { verze adaptací): }\end{array}$ & $\begin{array}{l}\text { Test of Memory and Learning - Second } \\
\text { Edition }\end{array}$ \\
\hline 1.4 & Autoři původního testu: & Cecil R. Reynolds a Judith K. Voress \\
\hline 1.3 & Autoři lokální adaptace: & $\begin{array}{l}\text { Jiří Laciga, Daniel Dostál, Dagmar Brejlová, } \\
\text { Miroslav Zárecký, Adéla Rajsiglová }\end{array}$ \\
\hline 1.7 & Lokální distributor/vydavatel testu: & Propsyco, s.r.o. \\
\hline 1.8 & $\begin{array}{l}\text { Vydavatel původní verze testu (pokud je } \\
\text { jiný než současný distributor/vydavatel): }\end{array}$ & PRO-ED, inc. \\
\hline 1.9 .1 & Datum vydání současné revize/vydání: & 2007 \\
\hline 1.9 .2 & $\begin{array}{l}\text { Datum vydání adaptace pro lokální } \\
\text { užívání: }\end{array}$ & 2017 \\
\hline 1.9 .3 & Datum vydání původního testu: & 1994 \\
\hline
\end{tabular}




\section{Obecný popis nástroje}

Test paměti a učení - Druhé vydání (TOMAL-2) je komplexní testovou baterií pro posuzování pamětových schopností, která je určená pro populaci ve věku od 5 do 59 let. TOMAL-2 se soustředí na posouzení celkové paměti a verbální a neverbální paměti (Propsyco, 2017). Doplňkové subtesty cílí na posouzení specifických aspektů paměti, jakými jsou např́íklad verbální oddálené vybavení či prostorová pamět'. Dále umožňují oddělené posouzení paměti, pozornosti jako nutného předpokladu pro zapamatování informací a učení, které je s pamětí úzce spjato (Propsyco, 2017).

Základní baterie sestává z 8 subtestů určených jak k posouzení celkového skóru paměti, tak k posouzení verbální a neverbální paměti. Na verbální pamět' se zaměřují 4 základní subtesty (Pamět' na příběhy, Pamět' na slova, Pamět' na předměty a Pamět' na dvojice slov), které společně tvoří kompozitní Index verbální paměti. Na neverbální pamět' cílí rovněž 4 základní subtesty (Pamět' na tváře, Abstraktní vizuální pamět', Vizuální sekvenční pamět' a Pamět' na umístění), které utváří kompozitní Index neverbální paměti. Celková pamět' je hodnocena na základě kombinace všech 8 základních subtestů, které poskytují Kompozitní index paměti. Základní baterii rozšiřuje 6 doplňkových subtestů, a to 4 verbální (Opakování čísel dopředu, Opakování písmen dopředu, Opakování čísel pozpátku a Opakování písmen pozpátku) a 2 neverbální (Vizuální selektivní pamět’ a Manuální imitace). Na základě doplňkových subtestů lze vyvodit další kompozitní indexy, a to Index pozornosti/soustředění, Index sekvenčního vybavení, Index volného vybavení, Index asociačního vybavení a Index učení. Poslední kompozitní index, Index verbálního oddáleného vybavení, je získán na základě oddáleného vybavení základních subtestů Pamět' na příběhy a Pamět' na slova (Propsyco, 2017).

Původní, americkou verzi TOMAL-2 vytvořili Reynolds a Voress (2007) - jedná se o revizi testu TOMAL, který byl určen pro děti a dospívající ve věkovém rozmezí od 5 do 19 let (Reynolds \& Bigler, 1994). Reynolds a Voress (2007) provedli oproti TOMAL několik změn. Byly vyřazeny některé položky, subtest Vizuální selektivní pamět' byl přesunut do doplňkových subtestů, byla upravena kritéria pro bazální úroveň a strop a pro nízkou reliabilitu byly vyřazeny subtesty na oddálené neverbální vybavení. Všechny položky TOMAL-2 však vychází z původního TOMAL. Z celkového počtu 1961 osob, které tvoří standardizační vzorek TOMAL-2, pochází 1382 z prvotní standardizace TOMAL (Propsyco, 2017).

Reynolds a Voress (2012) vytvořili také seniorskou verzi TOMAL-SE (Test of Memory and LearningSenior Edition), která byla normována pro dospělé ve věkovém rozpětí od 55 do 89 let. V České republice právě probíhá standardizace této verze (Katedra psychologie FSS, 2019).

TOMAL-2 lze využít $\mathrm{v}$ oblasti klinické psychologie a neuropsychologie (např. u epilepsie, traumatických poranění mozku či demence), a to jak u dětí (především u poruch učení či poruch pozornosti), tak u dospělých (Propsyco, 2019).

TOMAL-2 je administrován individuálně, interaktivně a formou tužka-papír. Administrace základní baterie trvá 30-35 minut. Administrace všech doplňkových subtestů zabere dalších 25-35 minut. TOMAL-2 spadá do kategorie $C$, což znamená, že metodu je oprávněn používat pouze absolvent magisterského studia psychologie (Propsyco, 2019). Všechny důležité pokyny pro zadávání jednotlivých subtestů a prostor pro zaznamenání odpovědí a pro součet hrubých skórů jsou k dispozici v Záznamové př́ručce. Vyhodnocení je možné ručně i on-line.

Metoda pracuje s několika druhy skórů. Hrubé skóry subtestů, které představují součet bodů získaných v subtestu, se převádí na standardní skóry subtestů $(\mathrm{M}=10, \mathrm{SD}=3)$. Standardní skóry indexů jsou získány součtem standardních skórů odpovídajících subtestů a jejich převodem $(\mathrm{M}=100, \mathrm{SD}=15)$. Pro standardní skóry subtestů i pro standardní skóry indexů jsou navíc ve stejných tabulkách uvedeny také percentily. $\mathrm{V}$ př́lohách má uživatel dále $\mathrm{k}$ dispozici tabulky pro převod standardních skórů subtestů a standardních skórů indexů na T-skóry, z-skóry, staniny, ekvivalenty normálního rozložení a věkové ekvivalenty, přičemž autoři upozorňují na nevýhody věkových ekvivalentů. Ruční i on-line vyhodnocení umožňují zakreslení kř̌ivky učení klienta na základě subtestů, u kterých dochází 
k opakované prezentaci podnětů, a její srovnání s průměrnými hodnotami věkové skupiny klienta. Dopočítat lze statistickou významnost rozdílu mezi základními kompozitními indexy.

\section{Část 2:}

\section{Klasifikace}

\begin{tabular}{|c|c|c|}
\hline 1.10 .1 & Obsahová doména & $\begin{array}{ll} & \text { Školní schopnosti } \\
\square & \text { Všeobecné schopnosti } \\
\square & \text { Verbální schopnosti } \\
\square & \text { Numerické schopnosti } \\
\square & \text { Prostorové schopnosti } \\
\square & \text { Neverbální schopnosti } \\
\square & \text { Rychlost vnímání } \\
\text { Q } & \text { Pamět' } \\
\square & \text { Manuální zručnost } \\
\square & \text { Osobnost - Rys } \\
\square & \text { Osobnost - Typ } \\
\square & \text { Osobnost - Stav } \\
\square & \text { Kognitivní styly } \\
\square & \text { Motivace } \\
\square & \text { Hodnoty } \\
\square & \text { Zájmy } \\
\square & \text { Přesvědčení } \\
\square & \text { Poruchy a patologie } \\
\square & \text { Skupinové procesy } \\
\square & \text { Rodina } \\
\square & \text { Organizace, její fungování, agregovaná } \\
\text { měření, klima atd. } \\
\square \text { Školní nebo výchovné funkce } \\
\square \text { Jiné: }\end{array}$ \\
\hline 1.10 .2 & $\begin{array}{l}\text { Zamýšlená(é) nebo hlavní oblast(i) } \\
\text { použití. }\end{array}$ & $\begin{array}{ll} & \text { Klinická psychologie } \\
\bigotimes & \text { Neuropsychologie } \\
\square & \text { Forenzní psychologie } \\
\bigotimes & \text { Psychologie výchovy a vzdělávání } \\
\square & \text { Psychologie práce a personalistika } \\
\bigotimes & \text { Poradenství, doporučení, vedení a volba } \\
& \text { povolání } \\
\square & \text { Psychologie zdraví, životní styl a životní } \\
& \text { spokojenost } \\
\square & \text { Sporty a volný čas } \\
\square & \text { Jiné: }\end{array}$ \\
\hline
\end{tabular}




\begin{tabular}{|c|c|c|}
\hline 1.10 .3 & $\begin{array}{l}\text { Zamýšlený způsob použití } \\
\text { (podmínky, za jakých byl nástroj } \\
\text { standardizován a validizován) }\end{array}$ & $\begin{array}{l}\text { Nesupervidovaná administrace bez } \\
\text { kontroly nad identitou respondenta a bez } \\
\text { úplné kontroly nad podmínkami } \\
\text { administrace (např. volně př́ístupný test } \\
\text { na internetu, test dostupný ke koupi v } \\
\text { knihkupectví). } \\
\text { Kontrolovaný nesupervidovanou } \\
\text { administrcí. Kontrola nad podmínkami } \\
\text { (čas atd.) a určitá kontrola nad identitou } \\
\text { uživatele testu (např. testy } \\
\text { administrované přes internet, ale pouze } \\
\text { známým osobám - př́ístup omezený } \\
\text { heslem). } \\
\text { Supervidovaná a kontrolovaná } \\
\text { administrace. Administrace testu pod } \\
\text { kontrolou kvalifikovaného adminitrátora } \\
\text { nebo dohlízitele. } \\
\text { Řízená administrace. Administrace testu } \\
\text { prováděná pouze přes určená testovací } \\
\text { centra (napřr. programy hodnocení licencí } \\
\text { a certifikace). }\end{array}$ \\
\hline 1.10 .4 & $\begin{array}{l}\text { Popis populací, pro které je test } \\
\text { určen: }\end{array}$ & $\begin{array}{l}\text { Metoda je určena pro děti, adolescenty a } \\
\text { dospělé ve věkovém rozmezí od } 5 \text { do } 59 \text { let. }\end{array}$ \\
\hline
\end{tabular}




\begin{tabular}{|c|c|c|}
\hline 1.10 .5 & $\begin{array}{l}\text { Počet škál a krátký popis } \\
\text { proměnné nebo proměnných } \\
\text { měřených nástrojem }\end{array}$ & 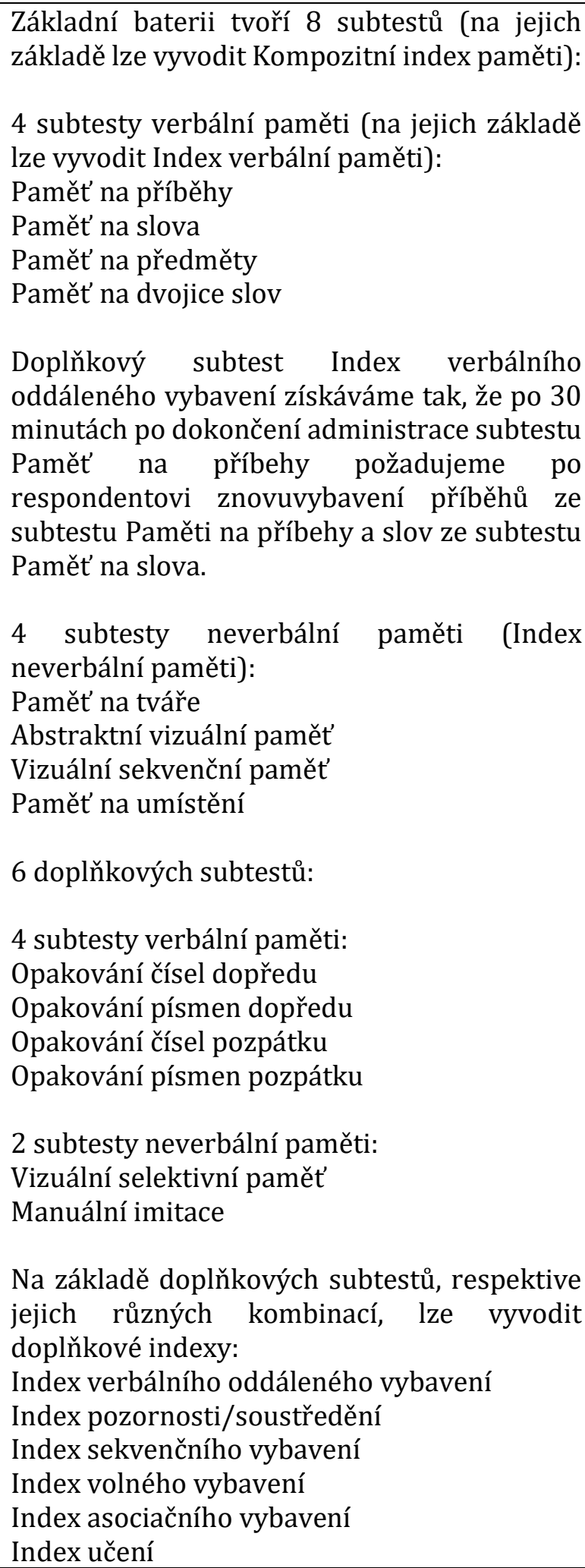 \\
\hline
\end{tabular}




\begin{tabular}{|c|c|c|}
\hline 1.11 & Formát položek & $\begin{array}{ll}\bigotimes & \text { Otevřený } \\
\square & \text { Mnohonásobná volba, alternativy na } \\
& \text { stejné škále } \\
\square & \text { Bipolární adjektiva } \\
\square & \text { Likertovy ratingy (škály) } \\
\square & \text { Nucená volba, alternativy na smíšených } \\
\text { škálách (ipsativní) - vysvětlení viz } \\
\text { Poznámky } \\
\square \text { Mnohonásobná volba, alternativy na } \\
\text { smíšených škálách (ipsativní) - } \\
\text { vysvětlení viz Poznámky } \\
\square \quad \text { Sady párů adjektiv (sémantický } \\
\text { diferenciál), smíšené škály (ipsativní) } \\
\square \quad \text { Jiné: }\end{array}$ \\
\hline 1.12 & Počet položek testu: & $\begin{array}{l}\text { Celkový počet položek TOMAL-2 činí } 837 \\
\text { položek pro věkové rozmezí } 9 \text { - } 59 \text { let a } 797 \\
\text { položek pro věkové rozmezí } 5-8 \text { let. } \\
\text { Vysoký počet položek TOMAL-2 je dán tím, že } \\
\text { každý podnět vybavený na správném místě je } \\
\text { skórován jako samostatná položka, a to za } \\
\text { účelem navýšení reliability. Pokud člověk } \\
\text { např. v subtestu Opakování čísel dopředu } \\
\text { udělá v sekvenci chybu, stále se mu } \\
\text { započítávají body za všechna ostatní čísla } \\
\text { vybavená na správném místě. }\end{array}$ \\
\hline 1.13 & Způsob(y) administrace: & $\begin{array}{ll}\otimes & \text { Interaktivní individuální administrace } \\
\square & \text { Supervidovaná skupinová administrace } \\
\square & \text { Počítačová lokálně nainstalovaná } \\
\text { aplikace - pod supervizí/dohledem } \\
\square & \text { Počítačová aplikace na webu - pod } \\
\text { supervizí/dohledem } \\
\square \\
\text { Počítačová lokálně nainstalovaná } \\
\text { aplikace - bez supervise/testování sebe } \\
\square \\
\text { Počítačová aplikace na webu - bez } \\
\text { supervize/testování sebe } \\
\square \text { Jiné: }\end{array}$ \\
\hline 1.14 & Způsob odpovídání: & $\begin{array}{ll}\bigotimes & \text { Ústní rozhovor } \\
\square & \text { Papír a tužka } \\
\bigotimes & \text { Manuální operace } \\
\square & \text { Na počítači } \\
\square & \text { Jiné: }\end{array}$ \\
\hline
\end{tabular}




\begin{tabular}{|c|c|c|}
\hline 1.15 & $\begin{array}{l}\text { Čas potřebný pro administraci } \\
\text { nástroje: } \\
\text { Čas na př́ípravu (čas, který zabere } \\
\text { administrátorovi připravit a rozložit } \\
\text { materiály pro diagnostické sezení). } \\
\text { - Čas na administraci na sezení: zahrnuje } \\
\text { čas potřebný pro dokončení všech } \\
\text { položek a odhad času potřebného pro } \\
\text { podání instrukcí, projití zácvičných } \\
\text { položek a nějaké doplňující komentáře } \\
\text { na konci sezení. } \\
\text { - Skórování: čas nutný pro získání } \\
\text { hrubých skórů. } \\
\text { - Analýza: čas strávený prováděním } \\
\text { dalších prací s hrubými skóry, aby se z } \\
\text { nich odvodily další míry a zformulovala } \\
\text { rozumně úplná interpretace (za } \\
\text { předpokladu, že znáte nástroj). } \\
\text { Zpětná vazba: čas potřebný k př́pravě a } \\
\text { poskytnutí zpětné vazny vyšetřované } \\
\text { osobě. } \\
\text { Připouští se, že čas posledních dvou } \\
\text { komponent se může značně lišit - v závislosti } \\
\text { na kontextu, ve kterém se nástroj používá. } \\
\text { Ale aspoň nějaké údaje a komentáře budou } \\
\text { užitečné. }\end{array}$ & 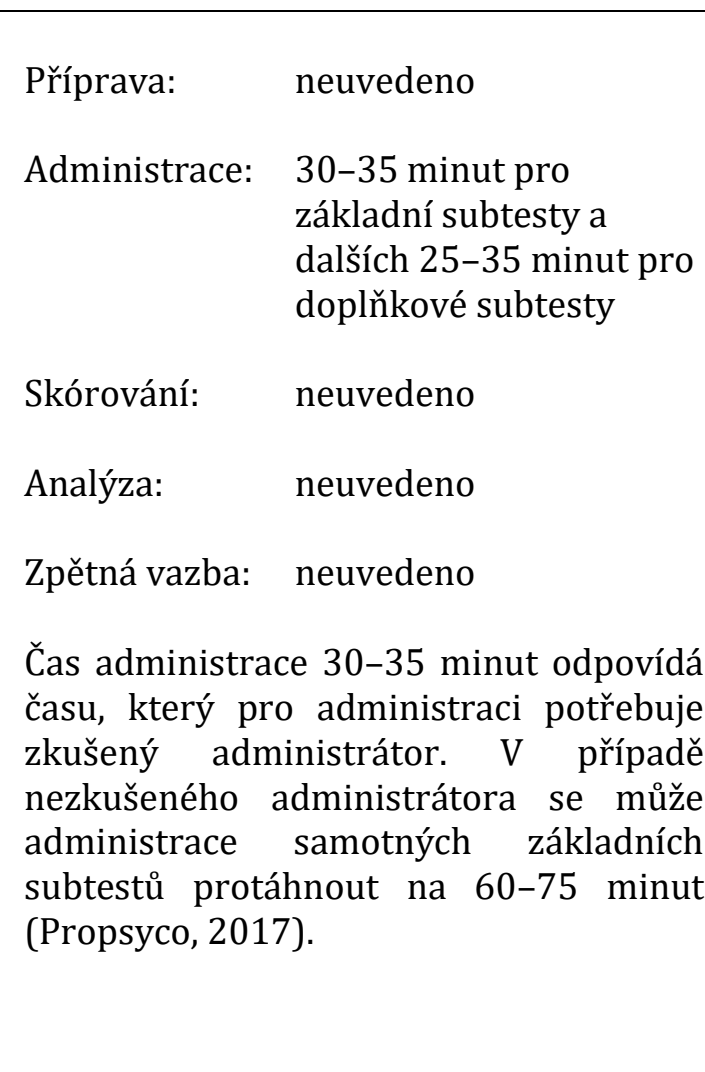 \\
\hline 1.16 & $\begin{array}{l}\text { Jsou k dispozici různé formy } \\
\text { nástroje? }\end{array}$ & $\begin{array}{l}\text { TOMAL-2 je k dispozici výhradně v tištěné } \\
\text { formě. } \\
\text { Zároveň v České republice právě probíhá } \\
\text { standardizace seniorské verze testu } \\
\text { TOMAL-SE, kterou vytvořili Reynolds a } \\
\text { Voress (2012) pro dospělé ve věku } 55 \text { až } \\
89 \text { let. }\end{array}$ \\
\hline
\end{tabular}

\section{Část 3:}

\section{Měření a skórování}

\begin{tabular}{|c|c|c|}
\hline 1.17 & Procedura skórování testu: & 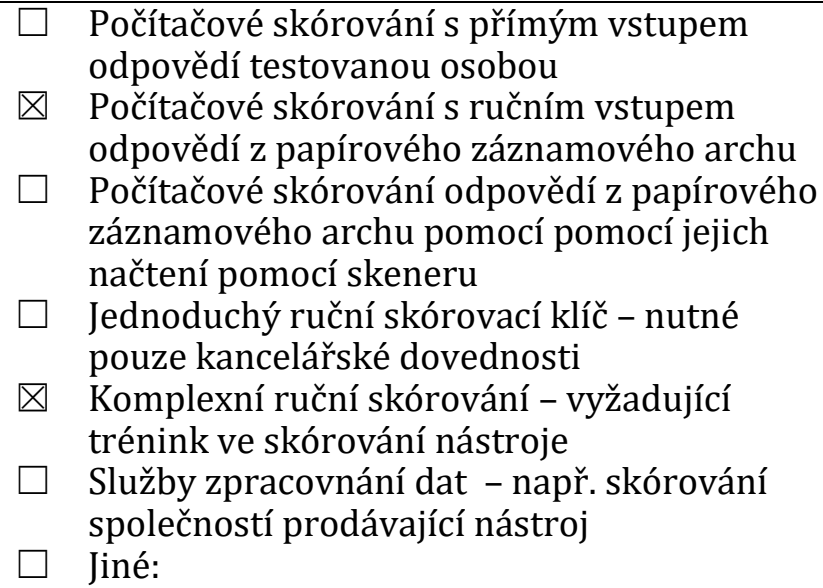 \\
\hline
\end{tabular}




\begin{tabular}{|c|c|c|}
\hline 1.18 & Skóry: & $\begin{array}{l}\text { Hrubé skóry subškál (tj. součet jednotlivých bodů } \\
\text { získaných za úlohy v subtestu) se převádí na } \\
\text { standardní skóry subškál }(\mathrm{M}=10, \mathrm{SD}=3) \text {. } \\
\text { Standardní skóry indexů se získávají součtem } \\
\text { standardních skórů odpovídajících subtestů a } \\
\text { jejich převodem pomocí tabulek (M = } 100, \mathrm{SD}= \\
\text { 15). Uživatel má dále k dispozici percentily, T- } \\
\text { skóry, z-skóry, staniny a ekvivalenty normálního } \\
\text { rozložení jak pro standardní skóry subtestů, tak } \\
\text { pro standardní skóry indexů. Pro věkové skupiny } \\
\text { v rozmezí } 5 \text { - } 14 \text { let jsou k dispozici také věkové } \\
\text { ekvivalenty. }\end{array}$ \\
\hline 1.19 & $\begin{array}{l}\text { Transformace skóru na standardní } \\
\text { skóry: }\end{array}$ & $\begin{array}{ll} & \text { Normalizovaná - skóry se získají použitím } \\
\text { normalizační tabulky } \\
\square \\
\text { Nenormalizovaná - skóry se získají lineární } \\
\text { transformací }\end{array}$ \\
\hline 1.20 & Použité škály & 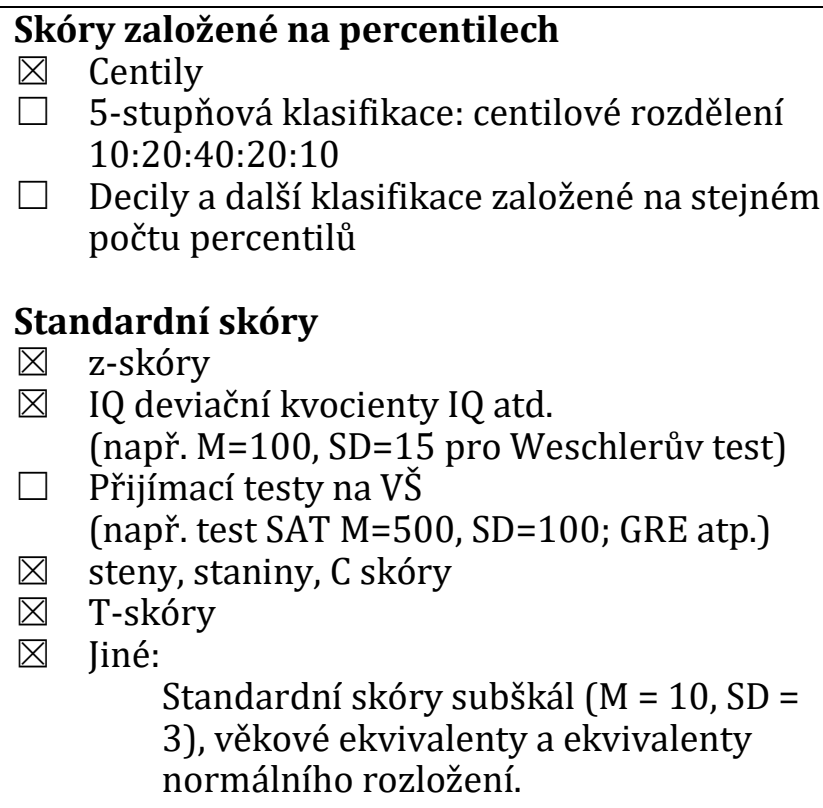 \\
\hline
\end{tabular}

\section{Č́st 4:}

\section{Počítačově generované zprávy}

Toto je čistě popisné. Hodnocení zpráv bude součástí části recenze nazvané Hodnocení.

\begin{tabular}{|l|l|ll|}
\hline 1.21 & $\begin{array}{l}\text { Jsou počítačově generované zprávy } \mathbf{k} \\
\text { dispozici s nástrojem? }\end{array}$ & $\square$ Ano \\
& $\bigotimes \quad \mathrm{Ne}$ \\
\hline
\end{tabular}

\section{Č́st 5:}

Nabídka, podmínky a náklady

Tato část definuje, co vydavatel poskytne, komu, za jakých podmínek a za jaké ceny. Definuje podmínky kladené dodavatelem a týkající se toho, kdo smí a kdo nesmí získat materiál nástroje. Pokud jedna z možností neodpovídá podmínkám nabídky, doplňte popis relevantních podmínek. 


\begin{tabular}{|c|c|c|}
\hline 1.23 & $\begin{array}{l}\text { Dokumentace poskytovaná } \\
\text { distributorem jako součást } \\
\text { testového balíku }\end{array}$ & 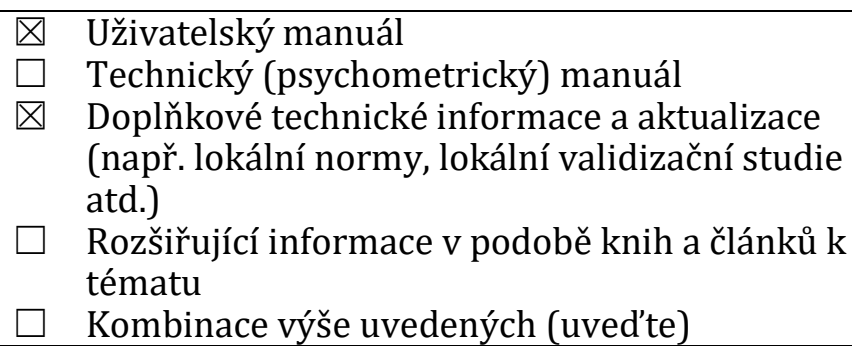 \\
\hline 1.24 & Metody publikace & $\begin{array}{ll} & \text { Papír } \\
\square & \text { PC - Diskety } \\
\square & \text { PC - CD/ROM } \\
\square & \text { Download z internetu } \\
\square & \text { Živý internet (nástroj pracuje v internetovém } \\
\text { prohlížeči) } \\
\square \text { Jiné: }\end{array}$ \\
\hline 1.25 .1 & $\begin{array}{l}\text { Počáteční náklady. } \\
\text { Cena kompletní sady materiálú (v̌̌echny manuály a } \\
\text { dalšś material nutný k aspoň jedné zkušební } \\
\text { administraci). Kolik uchazeču lze vyšetřovat pomocí } \\
\text { materiálu získaných za počáteční náklady, kde tyto } \\
\text { náklady zahrnují materially pro opakované vyšetření. }\end{array}$ & $\begin{array}{l}18 \text { 447,- Kč - úplný testový soubor: } \\
\text { Př́ručka (manuál) } \\
\text { Podnětová př́ručka A } \\
\text { Podnětová př́ručka B } \\
\text { Profilový list 30ks } \\
\text { Záznamový sešit 30ks } \\
\text { Vizuální selektivní pamět' 2ks } \\
\text { Oddálená pamět' na slova - Karty s nápovědou } \\
\text { Žetony - } 15 \text { kusů } \\
\text { Plátěná taška přes rameno } \\
\text { On-line vyhodnocení - } 100 \text { kreditů (časově } \\
\text { neomezeno) }\end{array}$ \\
\hline 1.25 .2 & Opakující se náklady: & $\begin{array}{l}\text { Záznamový sešit } 30 \mathrm{ks}-242,- \text { Kč } \\
\text { Profilový sešit } 30 \mathrm{ks}-150,- \text { Kč } \\
300 \text { kreditů pro on-line vyhodnocení - 1452,- Kč }\end{array}$ \\
\hline 1.26 .1 & $\begin{array}{l}\text { Ceny za zprávy generované } \\
\text { softwarem nainstalovaným } \\
\text { uživatelem: }\end{array}$ & \\
\hline 1.26 .2 & $\begin{array}{l}\text { Ceny za vyhotovení zprávy zaslené } \\
\text { prostřednictvím pošty/faxu: }\end{array}$ & \\
\hline 1.26 .3 & $\begin{array}{l}\text { Ceny za vyhotovení zprávy zaslené } \\
\text { prostř̌ednictvím internetové služby: }\end{array}$ & \\
\hline 1.27 & $\begin{array}{l}\text { Ceny za další služby a zpracování } \\
\text { dat: opravy nebo vývoj } \\
\text { automatických zpráv: }\end{array}$ & \\
\hline
\end{tabular}




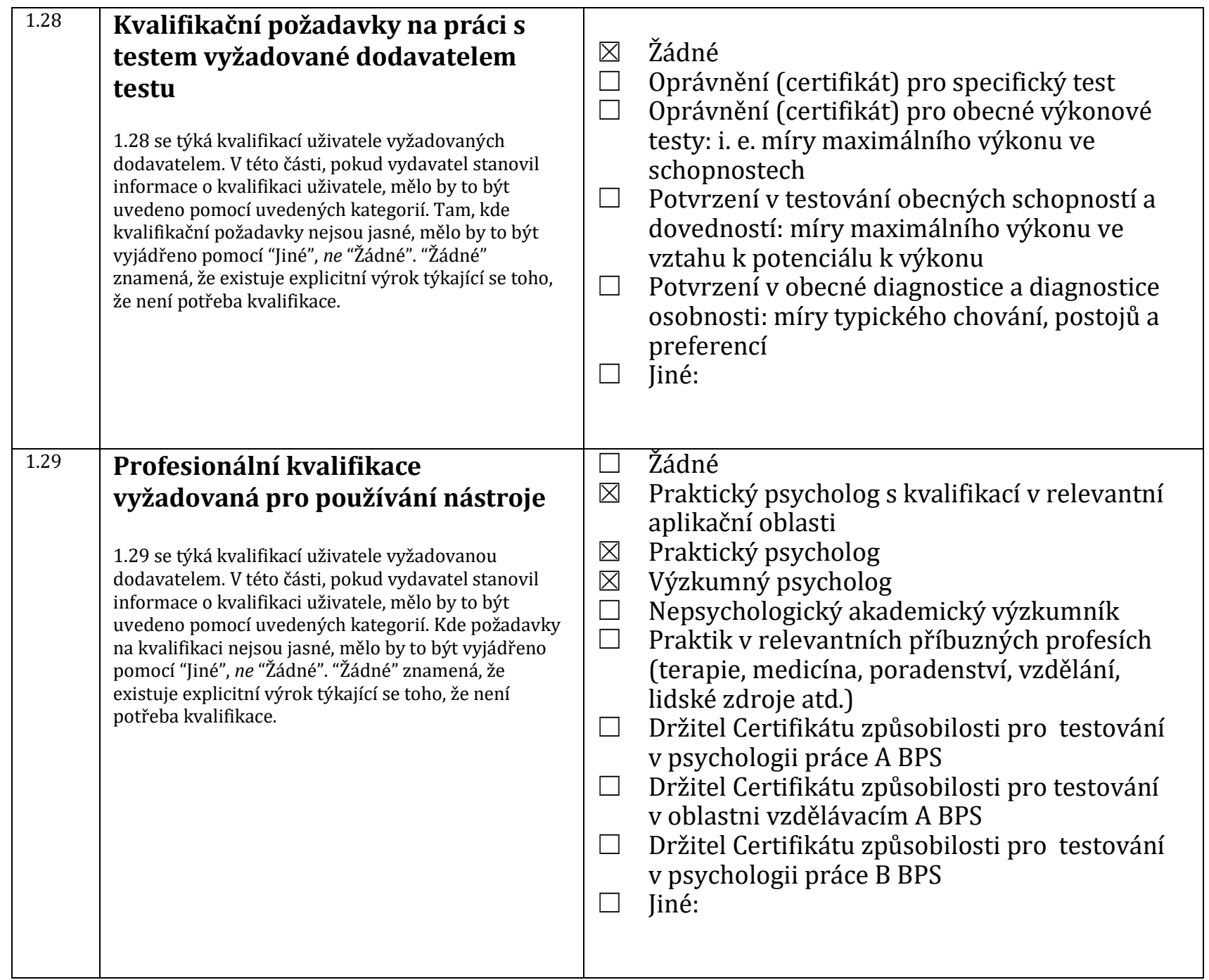

\section{Č́st 6:}

\section{Hodnocení testových materiálů}

\section{Vysvětlení hodnocení}

V následujících částech jsou celková posouzení adekvátnosti informací týkajících se validity, reliability a norem zobrazeny automaticky tučně.

Jakýkoli nástroj s jedním nebo více posouzeními 0 nebo 2 týkajícími se atributů považovaných za kritické pro bezpečné používání nástroje, by neměl být považován za nástroj, který splňuje minimální standardy. 


\begin{tabular}{|c|c|c|c|}
\hline $\begin{array}{l}\text { Vstup na posuzovacím } \\
\text { formuláři }\end{array}$ & $\begin{array}{l}\text { Posouzení podle } \\
\text { standardi̊ EFPA }\end{array}$ & $\begin{array}{c}\text { Reprezentace recenze } v \\
\mathrm{UK}\end{array}$ & Vysvětlení \\
\hline [n/a] & [n/a ] & [n/a ] & $\begin{array}{l}\text { Tento atribut není u tohoto } \\
\text { nástroje použitelný }\end{array}$ \\
\hline $\mathbf{0}$ & {$[-]$} & [None ] & $\begin{array}{l}\text { Není možné posoudit jako } \\
\text { ne nebo nedostatek } \\
\text { poskytnutých informací }\end{array}$ \\
\hline 1 & {$[-1]$} & {$\left[\begin{array}{ll}* & ]\end{array}\right.$} & Neadekvátní \\
\hline 2 & & {$\left[\begin{array}{ll}* * & ]\end{array}\right.$} & NYNÍ NEPOUŽÍVÁNO \\
\hline 3 & {$\left[\begin{array}{ll}0 & 0\end{array}\right]$} & {$[* * *]$} & Adekvátní nebo přiměřený \\
\hline 4 & [ 1 ] & {$[* * * *]$} & Dobrý \\
\hline \multirow[t]{2}{*}{5} & [ 2 ] & {$[* * * * *]$} & Vynikající \\
\hline & & $\begin{array}{l}\text { [N.r.i.o.r] }{ }^{*} \text { (pouze pro } \\
\text { aktualizace) }\end{array}$ & $\begin{array}{l}\text { Položka nebyla v původní } \\
\text { recenzi posuzována }\end{array}$ \\
\hline
\end{tabular}

V této části má být provedeno více hodnocení různých aspektů nebo atributů dokumentace dodávané s nástrojem (nebo balíkem). Termín „dokumentace“ byl vybrán, aby pokrýval všechny ty materiály dodávané s nástrojem nebo snadno dostupné kvalifikovanému uživateli: např. manual administrátora; technické př́ručky; brožury s normami; dodatky k manuálu; aktualizace od vydavatelů/dodavatelů atd.

Položky mají být posuzovány n/a nebo 0 až 5 (poloviční rating je přijatelný)

Rating

\begin{tabular}{|c|c|c|}
\hline \multicolumn{2}{|c|}{$\begin{array}{l}\text { Kvalita vysvětlení principů, prezentace a kvalita poskytnuté informace: } \\
\text { (Tento celkový rating se získá použitím posouzení založeného na ratinzích daných pro položky 2.1-2.8) }\end{array}$} & \multirow{2}{*}{4} \\
\hline 2.1 & $\begin{array}{l}\text { Celkový rating kvality vysvětlení principů: (Tento celkový rating se získá použitím } \\
\text { posouzení založeného na hodnotách ratingů daných pro položky } 2.1 .1-2.1 .5 \text { ) }\end{array}$ & \\
\hline 2.1 .1 & i) Teoretické základy konstruktů: & 5 \\
\hline 2.1 .2 & ii) Procedura vývoje testu: & 4 \\
\hline 2.1 .3 & iii) Důkladnost analýz položek a model analýzy položek: & 1 \\
\hline 2.1 .4 & iv) Vysvětlení obsahové validity: & 4 \\
\hline 2.1 .5 & v) Souhrn relevantního výzkumu: & 4 \\
\hline 2.2 & $\begin{array}{l}\text { Adekvátnost dokumentace dostupné uživateli (uživatelské a technické } \\
\text { manuály, dodatky týkající se norem atd.): (Tento celkový rating se získá použitím } \\
\text { posouzení založeného na hodnotách ratingů daných pro položky } 2.2 .1-2.2 .6 \text { ) } \\
\text { Pro část } 2.2 \text { jsou stanoveny následující „měřítka“ pro rating „vynikajíci““ (5). Pozornost je zde zaměřena } \\
\text { na kvalitu pokrytí poskytnutého v dokumentaci dostupné kvalifikovaným uživatelům. V̌̌imněte si, že část } \\
2.2 \text { se týká úplnosti a jasnosti dokumentace dostupné uživateli (uživatelské a technické manually, doadtky } \\
\text { k normám atd.) v pojmech pokrytía vysvětlení. V pojmech kvality nástroje, jak ji dosvědčuje dokumentace, } \\
\text { jsou rozpracovány oblasti v této části pod čísly: } 2.1,2.3,2.9,2.10 \text { a } 2.11 \text {. }\end{array}$ & 4 \\
\hline 2.2 .1 & $\begin{array}{l}\text { Principy: [viz 2.1] } \\
\text { Dobře argumentovaný a jasně prezentovaný popis toho, co má podle návrhu měřit a proč byl zkonstruován } \\
\text { tak, jak je. }\end{array}$ & 5 \\
\hline 2.2 .2 & $\begin{array}{l}\text { Vývoj: } \\
\text { Úplné detaily týkající se zdrojů položek, pilotáže, analýz položek, srovnávacích studií a změn prováděných v } \\
\text { prủběhu vývojových pokusủ. }\end{array}$ & 1 \\
\hline 2.2 .3 & $\begin{array}{l}\text { Standardizace: } \\
\text { Jasné a detailní informace poskytnuté o velikostech a zdrojích standardizačního souboru a standardizační } \\
\text { proceduře. }\end{array}$ & 5 \\
\hline 2.2 .4 & $\begin{array}{l}\text { Normy: } \\
\text { Jasné a detailní informace poskytnuté o velikostech a zdrojích normalizačních skupin, podmínkách vyšetření } \\
\text { atd. }\end{array}$ & 5 \\
\hline 2.2 .5 & $\begin{array}{l}\text { Reliabilita: } \\
\text { Dobré vysvětlení reliability a široký rozsah měr vnitřní konsistence a retestu spolu s vysvětlením jejich } \\
\text { relevance a zobecnitelnosti nástroje vyšetření. }\end{array}$ & 5 \\
\hline 2.2 .6 & $\begin{array}{l}\text { Validita: } \\
\text { Dobré vysvětlení validity spolu s širokou škálou studií jasně a poctivě popsaných. }\end{array}$ & 5 \\
\hline
\end{tabular}




\begin{tabular}{|c|c|c|}
\hline 2.3 & $\begin{array}{l}\text { Kvalita procedurálních instrukcí poskytnutých uživateli: (Tento celkový rating se } \\
\text { získá s použitím posouzení na základě hodnot ratingủ daných pro položky 2.3.1 - 2.3.7) }\end{array}$ & 5 \\
\hline \begin{tabular}{l|l}
2.3 .1 \\
\end{tabular} & $\begin{array}{l}\text { Pro administraci testu: } \\
\text { Poskytnutá jasná a detailní vysvětlení a procedurální průvodce krok za krokem spolu s dobrými radami } \\
\text { týkajíć́ćmi se otázek uchazeču a problémových situací. }\end{array}$ & 5 \\
\hline 2.3 .2 & $\begin{array}{l}\text { Pro skórování testu, normy atd.: } \\
\text { Poskytnuté jasné a detailńi informace spolu s popsanými kontrolami pro vyhnutí se možným chybám } \\
\text { skórování. }\end{array}$ & 5 \\
\hline 2.3 .3 & $\begin{array}{l}\text { Pro interpretaci a vytváření zpráv: } \\
\text { Detailní doporučení týkajííć se interpretace rủzných skórů, chápání normativních měr a zacházení se vztahy } \\
\text { mezi různými škálami, s mnžzstvím ilustrativních př́ikladú a př́padových studií. }\end{array}$ & 5 \\
\hline 2.3 .4 & $\begin{array}{l}\text { Pro poskytnutí zpětné vazby a debriefingu respondentům testu a dalším: } \\
\text { Detailní doporučení, jak prezentovat zpětnou vazbu uchazečům. }\end{array}$ & 0 \\
\hline 2.3 .5 & $\begin{array}{l}\text { Pro poskytování dobrých praktických témat týkajících se poctivosti a } \\
\text { zkreslení: } \\
\text { Uvedení detailních informací o studiích sexuálního a etnického zkreslenís relevantními varováními týkajícími } \\
\text { se použivání a zobecnováni validit. }\end{array}$ & 1 \\
\hline 2.3 .6 & $\begin{array}{l}\text { Omezení používání: } \\
\text { Jasné popisy, kdo by měl a kdo by neměl být vyšstřován spolu s dobře vysvětlenými odůvodněními těchto } \\
\text { omezení (napr.t typy nezpůsobilostí, požadované úrovně gramotnosti atd.). }\end{array}$ & 4 \\
\hline 2.3 .7 & $\begin{array}{l}\text { Reference a podpůrné materiály: } \\
\text { Detailní odkazy na relevantní podpưrnou akademickou literature a kř́ízové odkazy na další př́ibuzné } \\
\text { materially týkajíí se diagnostických nástrojủ. }\end{array}$ & 5 \\
\hline $\begin{array}{l}\text { Kval } \\
\text { (Tentc }\end{array}$ & $\begin{array}{l}\text { Materiálů: } \\
\text { ový rating se získá použitím posouzení založeného na hodnotách ratingů pro položky } 2.4-2.8 \text { ) }\end{array}$ & 4 \\
\hline 2.4 & $\begin{array}{l}\text { Všeobecná kvalita materiálů testu } \\
\text { (testové brožury, odpověd'ové archy, testové objekty, software atd.): }\end{array}$ & 5 \\
\hline 2.5 & Kvalita lokální adaptace testu (pokud byl test přeložen a adaptován do místního jazyka): & 3 \\
\hline 2.6 & Snadnost, s jakou může respondent testu porozumět úkolu: & 5 \\
\hline 2.7 & $\begin{array}{l}\text { Snadnost, s jakou mohou být respondentem testu tvořeny reakc } \\
\text { odpovědi: }\end{array}$ & 5 \\
\hline 2.8 & Kvalit & 4 \\
\hline \multicolumn{3}{|c|}{$\begin{array}{l}\text { Recenzentovy komentáře týkající se dokumentace: } \\
\text { (komentáře principů, designu, vývoje testu a jeho přijatelnosti) }\end{array}$} \\
\hline \multicolumn{3}{|c|}{$\begin{array}{l}\text { Teoretická východiska metody jsou velmi detailně popsána - věnuje se jim celá první kapitola českého } \\
\text { manuálu. Pečlivě jsou vysvětleny také postupy a instrukce pro administraci testu, skórování, } \\
\text { vyhodnocení a interpretaci testových skórů. Standardizace, ověřování reliability a ověřování validity } \\
\text { jsou rovněž podrobně dokumentovány, a to jak pro americkou, tak pro českou verzi testu. Jednou } \\
\text { výtkou, kterou lze vǔči této části mít, je, že je relativně náročné odlišit, které informace se týkají } \\
\text { americké a které české standardizace. }\end{array}$} \\
\hline \multicolumn{3}{|c|}{$\begin{array}{l}\text { Poněkud slabší je bohužel popis vývoje položek a popis adaptace položek a instrukcí do češtiny. } \\
\text { Vzhledem k tomu, že položky v TOMAL-2 představují výběr z položek původní verze testu TOMAL, } \\
\text { měly by se podrobnější analýza položek a dokumentace jejich vývoje nacházet v manuálu první verze } \\
\text { TOMAL (Adams \& Reynolds, 2009). K té však nemá běžný uživatel v České republice př́ístup. Autoři } \\
\text { české adaptace pak nepopisují ani překlad, ani adaptaci položek a testových instrukcí do češtiny. }\end{array}$} \\
\hline \multicolumn{3}{|c|}{$\begin{array}{l}\text { Podnětové materiály jsou výborně zpracované. Uživatelsky přívětivé jsou administrace i } \\
\text { vyhodnocování, a to jak on-line, tak ruční. Administraci značně usnadňuje kvalitní zpracování } \\
\text { Záznamové př́ručky, která obsahuje všechny pokyny pro zadávání subtestů i prostor pro } \\
\text { zaznamenání odpovědí a součet hrubých skórů. Uživatel tak nemusí opakovaně listovat v manuálu. } \\
\text { Vyhodnocení je možné pomocí Profilového listu a tabulek norem, reliabilit a standardních chyb } \\
\text { měření v manuálu, nebo on-line. On-line vyhodnocení nabízí rychlé, uživatelsky jednoduché } \\
\text { zpracování výsledků a součástí výstupu jsou navíc intervaly spolehlivosti, a to nejen pro standardní } \\
\text { skóry, ale v případě kompozitních indexŭ i pro percentily. }\end{array}$} \\
\hline
\end{tabular}




\section{Č́st 7: \\ Hodnocení norem, reliability a validity}

Rating

Informace o normách nebo referenční skupině

\begin{tabular}{|c|c|c|}
\hline 2.9 & Celková adekvátnost: & 5 \\
\hline 2.9 .1 & $\begin{array}{cl}\begin{array}{c}\text { Vhodnost pro lokální použití, at' už pro lokální nebo mezinárodní normy: } \\
\text { [n/a] }\end{array} & \text { Nepoužitelné } \\
0 & \text { Žádná informace nepodána. } \\
1 & \text { Není lokálně relevantní (např. nevhodné zahraniční výběry). } \\
3 & \begin{array}{l}\text { Lokální výběr z obecné populace nebo nelokální normy, které lze } \\
\text { použít s varováním. }\end{array} \\
4 & \begin{array}{l}\text { Výběry lokální země nebo relevantní mezinárodní výběry s dobrou } \\
\text { relevancí pro zamýšlenou aplikaci. }\end{array} \\
5 & \begin{array}{l}\text { Výběry lokální zemé nebo relevantní mezinárodní výběry vybrané z } \\
\text { dobře definovaných výběrü z relevantních aplikačních oblastí. }\end{array} \\
\end{array}$ & 5 \\
\hline 2.9 .2 & $\begin{array}{cl}\begin{array}{l}\text { Vhodnost pro zamýšlené aplikace: } \\
\text { [n/a] }\end{array} & \text { Nepoužitelné } \\
0 & \text { Žádná informace nepodána. } \\
1 & \text { Norma nebo normy nejsou adekvátní pro zamýšlené aplikace. } \\
3 & \begin{array}{l}\text { Adekvátní normy pro obecnou populaci a/nebo rozmezí normativních } \\
\text { tabulek. }\end{array} \\
4 & \begin{array}{l}\text { Dobré rozmezí normativních tabulek. } \\
5\end{array} \\
\begin{array}{l}\text { Vynikajíí rozmezí výběrově relevantních norem vztahujících se k věku } \\
\text { a pohlaví, s informacemi o dalších rozdílech v rámci skupin (např. } \\
\text { směs etnických skupin). }\end{array} \\
\end{array}$ & 5 \\
\hline 2.9 .3 & 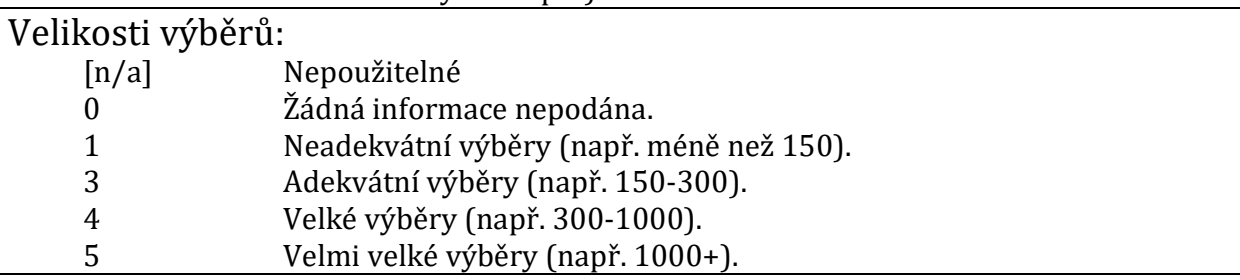 & 4 \\
\hline 2.9 .4 & 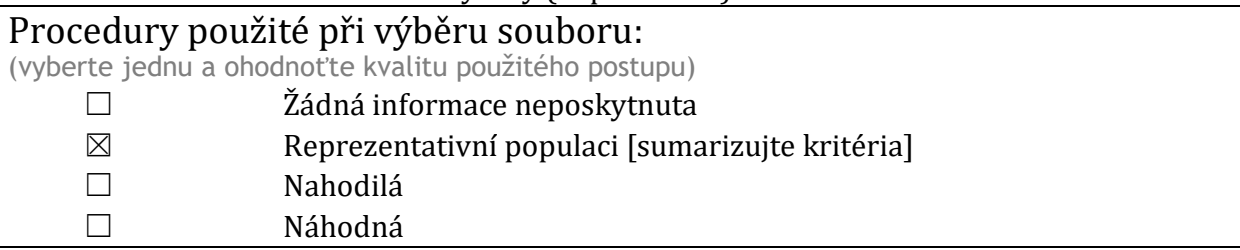 & 5 \\
\hline 2.9 .5 & $\begin{array}{ll}\text { Kvalita informací poskytnutých o minoritní/chráněné skupině, rozdílech, } \\
\text { vlivech věku, rodu atd.: } \\
\begin{array}{ll}\text { [n/a] } & \text { Nepoužitelné } \\
0 & \text { Žádná informace nepodána. } \\
1 & \text { Neadekvátní informace. } \\
3 & \text { Adekvátní obecné informace s minimální analýzou. } \\
4 & \text { Dobré popisy a analýzy skupin a rozdílù } \\
5 & \text { Vynikajíć série analýz a diskuse o relevantních tématech vztahujících } \\
& \text { se k použití a interpretaci. }\end{array} \\
\end{array}$ & 3 \\
\hline
\end{tabular}


Česká standardizační studie byla provedena na vzorku 925 osob ve věku 5 let až 59 let a 11 měsíců. Standardizační soubor byl rozdělen do 24 věkových skupin. Autoři testu se snažili zajistit reprezentativní vzorek, a to s využitím informací o demografických charakteristikách české populace ze Sčítání lidu, domů a bytů v roce 2011. Soubor se autoři snažili vyvážit z hlediska počtu mužů a žen, velikosti bydliště, nejvyššího dosaženého vzdělání v př́padě dospělých a nejvyššího dosaženého vzdělání rodičů a typu školy $\mathrm{v}$ případě dětí a adolescentů. Zastoupení v jednotlivých kategoriích odpovídá očekávaným procentům výskytu $\mathrm{v}$ populaci kromě nejvyššího dosaženého vzdělání v kategoriích dospělých respondentů. Podařilo se dodržet zastoupení osob s maturitou a s výučním listem, ale $\mathrm{v}$ prípadě osob $\mathrm{s}$ vysokoškolským vzděláním a osob se základním vzděláním došlo k mírnému odchýlení. Zatímco v populaci se podíl vysokoškoláků v jednotlivých věkových skupinách pohyboval mezi 12 až $23 \%$, ve standardizačním souboru se pohyboval mezi 20 až $27 \%$. Podíl osob se základním vzděláním v jednotlivých věkových skupinách se v populaci pohyboval mezi 10 až 17 \% a ve standardizačním souboru pak mezi 3 až $10 \%$. Autoři shrnují, že standardizační soubor lze považovat za o něco vzdělanější, než by odpovídalo populaci, avšak odchylka je poměrně malá (Propsyco, 2017).

Vzorek 925 se jeví jako velký, ale je důležité zdůraznit, že do jednotlivých věkových kategorií spadá 74 až 183 osob. Tento problém autoři české verze adresovali. Použili komplexní postup k vyhlazování, který podrobně dokumentují v manuálu. Rozhodli se zohlednit fakt, že tvary rozložení hrubých skórů jsou v případě TOMAL-2 velmi různorodé. Zohledněn byl také požadavek na to, aby standardní skóry odpovídaly vývojové křivce kognitivních schopností (Propsyco, 2017). Velikost vzorku v jednotlivých věkových skupinách lze v důsledku považovat za velmi dobrou (Iliescu, 2017).

Pro uživatele je užitečné zmínit také efekt stropu a efekt podlahy, které jsou přítomné v některých věkových skupinách a které by měli uživatelé při interpretaci výsledků zohlednit. Efekt stropu se týká zejména věkové skupiny 20 až 29 let, zatímco efekt podlahy je patrný v mladších věkových kategoriích.

\section{Validita}

\begin{tabular}{|c|c|c|}
\hline 2.10 & $\begin{array}{l}\text { Celková adekvátnost: (Tento celkový rating se získá na základě posouzení hodnot ratingů } \\
\text { daných v položkách } 2.10 .1-2.10 .2 .4 \text {. Neprůměrujte pouze čísla, abyste získali celkový rating. } \\
\text { Obvykle bude roven bud' konstruktové validitě nebo validitě vztahující se ke kritériu, podle } \\
\text { toho, která z nich je vyšší.) }\end{array}$ & 5 \\
\hline 2.10 .1 & $\begin{array}{l}\text { Konstruktová validita - celková adekvátnost } \\
\text { (Tento celkový rating se získá na základě posouzení hodnot ratingů daných v položkách } \\
2.10 .1 .2-2.10 .1 .6 \text {. Neprüměrujte pouze čísla, abyste tento celkový rating získali.) }\end{array}$ & 5 \\
\hline 2.10 .1 .1 & $\begin{array}{cl}\text { Použité plány: (zatrhněte tolik, kolik je jich použitelných) } \\
\square \quad \text { Žádná informace nepodána } \\
\square \quad \text { Korelace s dalšími nástroji a výkonovými kritérii } \\
\square \quad \text { Vnitroškálový (korelace položky se zbytkem) } \\
\bigotimes \quad \text { Rozdíly mezi skupinami } \\
\square \quad \text { Matice mnoha rysů a mnoha metod (MTMM) } \\
\square \quad \text { Explorační faktorová analýza } \\
\square \quad \text { Konfirmační faktorová analýza } \\
\square \quad \text { Experimentální plány } \\
\square \quad \text { Jiné: }\end{array}$ & \\
\hline 2.10 .1 .2 & $\begin{array}{cl}\begin{array}{l}\text { Velikosti výběrů: } \\
0\end{array} & \text { Žádná informace neposkytnuta. } \\
1 & \text { Jedna neadekvátní studie (např. velikost výběru menší než 100). } \\
3 & \text { Jedna adekvátní studie (např. velikost výběru 100-200). } \\
4 & \text { Více než jedna adekvátní nebo velká studie. } \\
5 & \text { Dobrá série adekvátních až rozsáhlých studií. } \\
\end{array}$ & 4 \\
\hline 2.10 .1 .3 & $\begin{aligned} \text { Procedura výběru souboru: (vyberte jednu) } \\
\square \quad \text { Žadná informace neposkytnuta } \\
\square \quad \text { Reprezentativní vǔči populaci [sumarizujte kritéria] } \\
\square \quad \text { Nahodilá } \\
\square \quad \text { Náhodná }\end{aligned}$ & \\
\hline
\end{tabular}




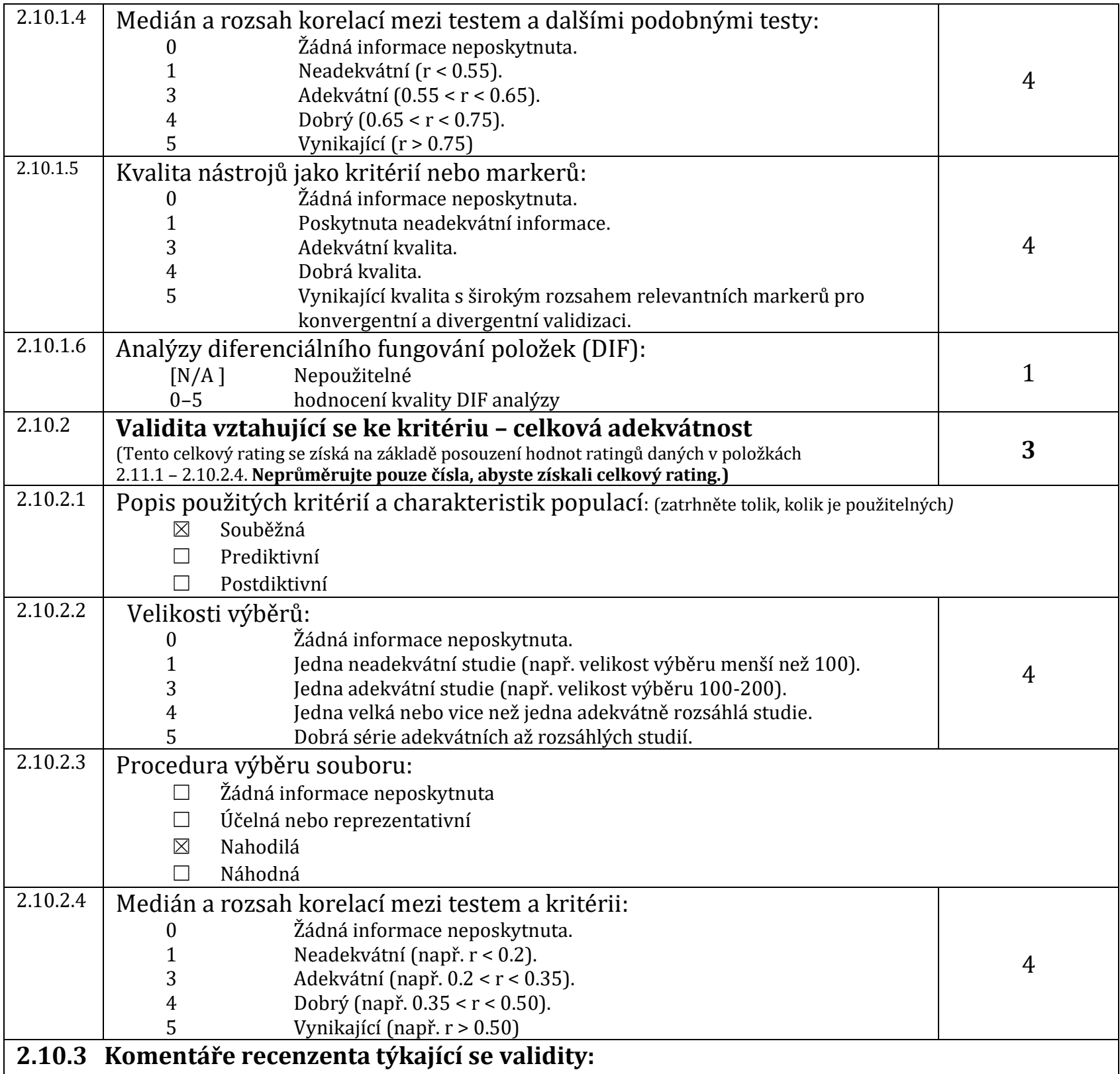

Autoři české adaptace metody věnovali nadstandardní péči posouzení konstruktové validity pomocí konfirmační faktorové analýzy, přičemž $\mathrm{v}$ tomto ohledu daleko překračují úroveň amerického manuálu. Velmi dobré shody modelu s daty dosáhly všechny hypotetizované modely, a tak autoři přistoupili k bifaktorovému řešení. Finální bifaktorové řešení dosáhlo vynikající shody modelu s daty. Předkládá existenci jednoho faktoru kompozitní paměti, který sytí každý z 8 základních subtestů, faktoru verbální paměti sytícího verbální subtesty a faktoru neverbální paměti sytícího neverbální subtesty. Autoři rovněž vypočetli hierarchickou McDonaldovu omegu, která dosáhla hodnoty 0,72 , a celkovou McDonaldovu omegu, která dosáhla hodnoty 0,85. Na základě těchto výsledků lze vyvodit, že bifaktorový model dokázal vysvětlit 85 \% rozptylu vážených skórů základních subtestů, přičemž 72 $\%$ tohoto rozptylu vysvětluje obecný, kompozitní faktor paměti a $13 \%$ faktor verbální paměti a faktor neverbální paměti (Propsyco, 2017). Použití hierarchické a celkové McDonaldovy omegy opět dalekosáhle překračuje běžný standard nejen českých, ale i zahraničních standardizací.

Předpoklad, že pamět' podobně jako další kognitivní schopnosti závisí na věku, ověřovali autoři české verze pomocí vývojových křivek s využitím dat celého standardizačního souboru. Průběh vývojových křivek odpovídal očekávání (Propsyco, 2017). 
Ke kriteriální validitě autoři přistoupili na základě předpokladu, že pamětové schopnosti a schopnost učit se úzce souvisí s tím, jakého vzdělání člověk dosáhne. Zjišțovali souvislost mezi výsledky v TOMAL-2 a dosaženým vzděláním. Použili údaje respondentů starších 20 let ze standardizačního souboru $(\mathrm{N}=271)$. Do regresní analýzy nejprve zařadili pohlaví a věk, které společně vysvětlily $18 \%$ rozptylu výsledků v TOMAL-2. Přidáním proměnné vzdělání vzrostl podíl vysvětleného rozptylu o 32 $\%(\Delta \mathrm{R} 2=0,32) . \mathrm{V}$ př́padě respondentů do 20 let ze standardizačního souboru $(\mathrm{N}=653)$ zkoumali vztah mezi výsledky v TOMAL-2 a vzděláním rodičů. Pohlaví a věk vysvětlily $11 \%$ rozptylu výsledků v TOMAL-2. Zařazení vzdělání rodičů do modelu vedlo k nárůstu o dalších $13 \%(\Delta \mathrm{R} 2=0,13)$. Podle autorů tyto výsledky naznačují, že by TOMAL-2 mohl být použit k odhadnutí budoucího vzdělání či školní úspěšnosti (Propsyco, 2017). Důkazy o prediktivní validitě ovšem nepředkládají.

Další důkazy o validitě přejímají autoři české adaptace z amerického manuálu. Souběžnou validitu s ostatními nástroji měřícími pamět' demonstrují autoři americké verze na dvou studiích. Jedna z nich pochází z americké standardizace pamět'ového testu WRAML-2 (Wide Range Assessment of Memory and Learning). Ta srovnává WRAML-2 s první verzí TOMAL a zaměřuje se na děti a adolescenty (Sheslow \& Adams, 2003). Druhá pochází z americké standardizace TOMAL-2 a vzorek tvořili dospělí (Reynolds \& Voress, 2007). Sílu zjištěných korelací lze považovat za velmi dobrou $(r=0,69-0,79)$. Ve prospěch TOMAL-2 hovoří také středně silné až silné korelace s inteligenčními testy a s výkonovými testy ( $r=0,40-0,65$; Reynolds \& Voress, 2007), které naznačují, že test s inteligencí a s výkonem souvisí, ale zároveň má vůči inteligenčním a výkonovým testům inkrementální validitu (Propsyco, 2017). Podobné vzorce korelací se vyskytují i u WRAML-2 (Sheslow \& Adams, 2003).

Výhradu mám vůči tomu, že v manuálu není snadné odlišit důkazy z americké standardizace od důkazů $\mathrm{z}$ české standardizace. Navíc $\mathrm{v}$ př́ípadě americké standardizace pochází řada důkazů ze studií provedených s použitím první verze TOMAL, což lze do jisté míry ospravedlnit. TOMAL-2 obsahuje stejné položky jako TOMAL a standardizační vzorek TOMAL-2 zahrnuje původní standardizační vzorek TOMAL. Zásadní poznámkou však je, že TOMAL byl standardizován pouze pro věk 5 až 19 let (Reynolds \& Bigler, 1994), a tak validizační studie zahrnují pouze vzorky dětí a adolescentů. Dalším problémem je také to, že ačkoliv lze souhlasit s tím, že výsledky získané z TOMAL lze generalizovat také na TOMAL-2 (Schmitt \& Decker, 2008), při standardizaci TOMAL v 90. letech byly použity testy inteligence či výkonu, které již samy prošly revizí jako např. WISC-R (Dehn, 2010; Schmitt \& Decker, 2008).

Informace o obsahové validitě ve smyslu reprezentativního výběru položek $\mathrm{z}$ domény přebírají autoři české verze testu $\mathrm{z}$ amerického manuálu. Položky TOMAL-2 byly vybrány $\mathrm{z}$ položkové banky původního TOMAL. Tvorba položek pro TOMAL probíhala na základě klinických zkušeností obou autorů, studia teoretických a empirických poznatků o paměti a dostupných testů. Položky byly konzultovány s experty na konstrukt, kteří posuzovali, jaké kognitivní funkce jednotlivé subtesty primárně měří. Každý subtest byl podroben pilotáži, jejíž výsledky podnítily změny v administraci i testovém materiálu. Po každé změně byla provedena nová pilotáž (Reynolds \& Voress, 007). Podrobnější analýza položek a dokumentace jejich vývoje by měly být dostupné v manuálu první verze TOMAL (Adams \& Reynolds, 2009), kterou však nemá běžný český uživatel k dispozici. Autoři české adaptace bohužel nekomentují ani překlad a adaptaci položek a testových instrukcí do češtiny.

Z amerického manuálu jsou převzaty také informace o férovosti. Konkrétně bylo testováno zkreslení položek na základě pohlaví a na základě etnické příslušnosti. Použit byl Jensenův delta scores approach. Výsledky v podobě vysokých korelací (u všech položek vyšší než 0,9) mezi hodnotami delta naznačují vysokou podobnost fungování položek např́íč skupinami (Hartman, 2007; McCallum, 2003). Považuji ale za důležité podotknout, že diferenciální fungování položek bylo testováno pouze u původního standardizačního souboru TOMAL na počátku 90. let (Reynolds \& Bigler, 1994). Na základě výsledků nelze usuzovat na nezkreslenost položek v českém standardizačním souboru, což se v českém manuálu do určité míry děje. Autoři české verze na základě těchto údajů usuzují, že se povedlo dosáhnout stejného fungování položek pro muže i pro ženy a diskutují potenciální skutečné rozdíly v pamět'ových schopnostech mezi pohlavími v České republice (Propsyco, 2017). 
Vzhledem k tomu, že TOMAL a TOMAL-2 byly navrženy s důrazem na to, aby se jednalo o užitečné nástroje pro provádění klinického posouzení, lze předpokládat senzitivitu TOMAL-2 na neurologické poruchy, poruchy pozornosti s hyperaktivitou, traumatické poranění mozku či poruchy učení. Prvotní verze TOMAL se ukázala jako senzitivní na poruchy učení (Howes, Bigler, Lawson, \& Burlingame, 1999) i na traumatické poranění mozku (Lowther \& Mayfield, 2004). Za pozornost stojí také novější studie. Např́klad výsledky studie Thalera, Allena, McMurrayho a Mayfielda (2010) podpořily vhodnost TOMAL pro posuzování neuro-kognitivních deficitů u dětí s ADHD. Thaler, Barney, Reynolds, Mayfield a Allen (2011) nalezli další podporu pro senzitivitu TOMAL na traumatické poranění mozku.

\section{Reliabilita}

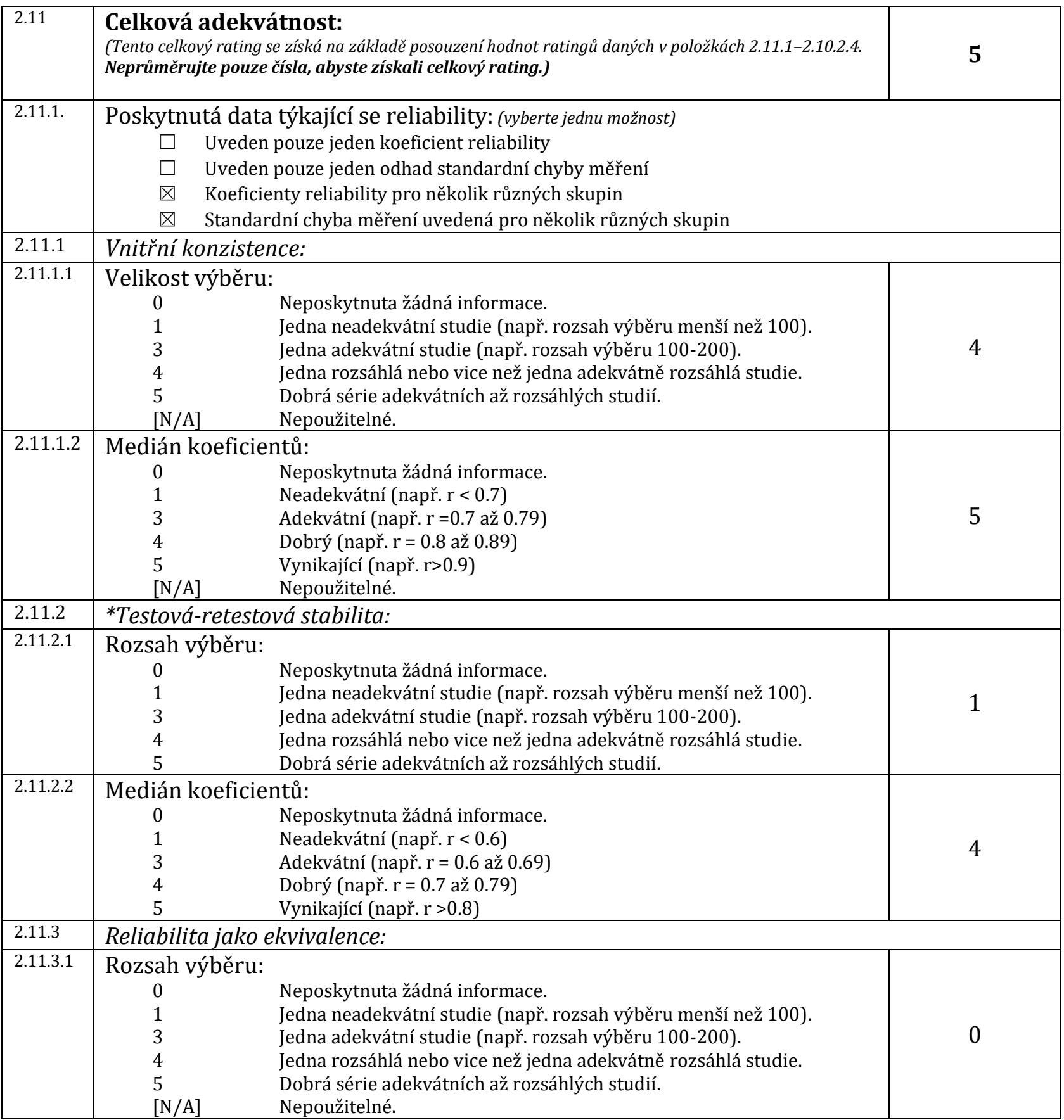




\begin{tabular}{|l|cl|c|}
\hline 2.11.3.2 & Medián koeficientů: & \\
& 0 & Neposkytnuta žádná informace. & \\
& 1 & Neadekvátní (např. $r<0.6$ ) & 0 \\
& 3 & Adekvátní (např. $r=0.6$ až 0.69) & \\
& 5 & Dobrý (např. $r=0.7$ až 0.79) & \\
& [N/A ] & Vynikající (např. $r>0.8$ ) & \\
\hline
\end{tabular}

2.11.4 Komentáře recenzentů k reliabilitě:

- Komentujte intervaly spolehlivosti pro koeficienty reliability

- Uved'te Spearmanovy-Brownovy ekvivalenty

Autoři české adaptace poskytují odhady reliability ve smyslu vnitřní konzistence a standardní chyby měření získané na českém standardizačním vzorku pro všechny dílčí subtesty i kompozitní indexy, a to např́č 8 věkovými skupinami. Reliability dosahují excelentních hodnot. Reliabilita Kompozitního indexu paměti neklesla v žádné věkové skupině pod $0,95 . \mathrm{V}$ př́padě Indexů verbální paměti a Indexů neverbální paměti neklesla pod 0,94. Mediány reliabilit všech základních indexů se pohybovaly v rozmezí $0,94-0,97$. V případě doplňkových indexů se mediány reliabilit pohybovaly v rozmezí $0,91-$ 0,97 s výjimkou Indexu verbálního oddáleného vybavení, u kterého dosáhl medián hodnoty 0,85. Mediány reliabilit např́č věkovými skupinami se u většiny základních i doplňkových subtestů pohybovaly v rozmezí $0,85-0,97$. Výjimku tvoří pamět' na tváře $(0,80)$, vizuální sekvenční pamět' $(0,80)$ a oddálená pamět' na slova $(0,70)$ (Propsyco, 2017).

Autoři české verze kritizují, že při americké standardizaci byla reliabilita subtestů odhadována pomocí Cronbachovy alfy (Propsyco, 2017). Tato výtka je opodstatněná vzhledem $\mathrm{k}$ př́snému předpokladu Cronbachovy alfy, kterým je tau-ekvivalence položek, přičemž nedodržení tohoto předpokladu vede $\mathrm{k}$ podhodnocení skutečné reliability. Namísto toho se autoři české adaptace rozhodli použít split-half reliabilitu spolu s korekcí pomocí Spearmanova-Brownova věšteckého vzorce, a to jak pro odhad reliabilit subtestů, tak pro odhad reliabilit kompozitních skórů. Autoři také položky každého subtestu seřadili podle jejich rozptylu a až poté je rozdělili na sudé a liché (Propsyco, 2017), pravděpodobně za účelem dosažení co nejpodobnějšího rozptylu obou polovin testu. Striktním předpokladem tohoto postupu jsou paralelní položky - při jeho nedodržení může být SpearmanůvBrownův věštecký vzorec př́liš optimistický a reliabilitu nadhodnotit. Pro odhad vnitřní konzistence subtestů by bylo vhodnější použít McDonaldovu omegu, která nevyžaduje tau-ekvivalenci, a pro odhad vnitřní konzistence kompozitních indexů např́́klad stratifikovanou Cronbachovu alfu, která by zohlednila vícedimenzionalitu těchto indexů. Nadstandardní je použití hierarchické McDonaldovy omegy $(\omega=0,72)$ a celkové McDonaldovy omegy $(\omega=0,85)$ pro odhad reliability konstruktu a posouzení významu faktorů $\mathrm{v}$ bifaktorovém modelu, pomocí kterého autoři ověřovali faktorovu strukturu metody. Autoři české adaptace rovněž upozorňují na to, že obeznámenost s různými koeficienty omega ( $\omega$ ) nepatří mezi běžné znalosti uživatelů testů (Propsyco, 2017). To mohlo přispět i k rozhodnutí autorů zvolit pro odhad reliabilit subtestů a indexů známější a více zaužívanou splithalf reliabilitu.

Na rozdíl od americké standardizace autoři bohužel zůstávají pouze na úrovni posouzení reliability ve smyslu vnitřní konzistence a neposkytují údaje o reliabilitě test-retest ani o shodě posuzovatelů. Odkazují se jen na informace $\mathrm{z}$ amerického manuálu (Propsyco, 2017). Reliabilita test-retest byla v americké verzi přijatelná (u základních indexů v rozmezí 0,71-0,94, u doplňkových 0,68-0,94), avšak provedená na malých vzorcích. Shoda posuzovatelů byla v americké verzi velmi dobrá 0,94 nebo vyšší), ačkoliv lze mít výhrady vůči použití prosté Pearsonovy korelace k jejímu posouzení.

*hodnocení testové-retestové stability vychází z amerických validizačních studií

\section{Část 9:}




\subsection{Hodnotící zpráva testu:}

Tato část by měla obsahovat stručné, jasně obhájené posouzení nástroje/produktu. Mělo by popisovat jeho pro a proti a poskytnout určitá obecná doporučení týkající se toho, jak a kdy by se měl používat - spolu s varováními (kde jsou potřebná) týkajícími se př́padů, kde by se používat neměl.

Velkou předností TOMAL-2 jsou kvalitní české normy pro 24 věkových skupin, přičemž menší počet respondentů $\mathrm{v}$ jednotlivých věkových kategoriích autoři české adaptace adekvátně vyřešili pomocí vyhlazování. Při tvorbě norem také zohlednili různorodost rozložení hrubých skórů subtestů TOMAL2 a vývojovou křivku kognitivních schopností. Při interpretaci by uživatelé měli mít na paměti efekty stropu ve věkové skupině od 20 do 29 let a efekty podlahy přítomné u nejmladších věkových skupin.

Dalším kladem české adaptace je posouzení konstruktové validity pomocí konfirmační faktorové analýzy, jejíž provedení je nadstandardně kvalitní. Ověření konstruktové validity české adaptace TOMAL-2 je tak dokonce na vyšší úrovni než ověření konstruktové validity americké verze testu. Z hlediska kriteriální validity autoři české adaptace provedli studii zaměřenou na vztah mezi TOMAL2 a dosaženým vzděláním $\mathrm{v}$ př́padě dospělých a studii zaměřenou na vztah mezi TOMAL-2 a dosaženým vzděláním rodičů v př́ípadě dětí a adolescentů. Důkazy o souběžné validitě s jinými testy přebírají z americké verze manuálu. Žádoucí by bylo provést další validizační studie, které by srovnaly výsledky v TOMAL-2 s výsledky $\mathrm{v}$ současné době používaných inteligenčních, výkonových a pamět'ových testů. Pro účely české adaptace by bylo ideální posoudit souběžnou validitu TOMAL-2 s jinými testy používanými v České republice, a to např́iklad s Wechslerovou pamět'ovou škálou WMSIII (Wechsler, 1999) nebo s Wechslerovou zkrácenou pamět'ovou škálou WMS-IIIa (Wechsler, 2011). Užitečná by byla také konormace TOMAL-2 s inteligenčními testy (např. Woodcock-Johnson IV). Konormace inteligenčních a pamět'ových testů umožňuje identifikovat diskrepance mezi inteligenčním a pamět’ovým výkonem, což je významné pro identifikaci organických a kognitivních poruch (Drozdick a kol., 2011). Velmi pozitivním vývojem je, že v současnosti probíhá konormace seniorské verze Testu paměti a učení TOMAL-SE s Testy školních dovedností (BACH), což umožní diagnostiku kognitivních poruch a organických poškození mozku u seniorské populace (Katedra psychologie FSS, 2019). Souhrnně lze validitu TOMAL-2 považovat za velmi dobrou.

Ocenění hodné je také to, že autoři české verze testu poskytují odhady reliability ve smyslu vnitřní konzistence a odhady standardní chyby měření pro všechny subtesty a všechny kompozitní indexy, a to zvlášt' pro 8 věkových skupin. Reliability navíc dosahují vynikajících hodnot, a to jak u kompozitních indexů, tak u jednotlivých subtestů. Mimořádně chvályhodné je, že autoři české adaptace přistoupili k odhadu reliability konstruktu pomocí hierarchické McDonaldovy omegy a celkové McDonaldovy omegy. Reliabilitu test-retest autoři české adaptace nezkoumali a přebírají ji $\mathrm{z}$ americké verze manuálu, což lze ovšem považovat za dostačující. Reliabilita české adaptace TOMAL-2 je celkově na vysoké úrovni.

Výborné je také zpracování podnětových materiálů a uživatelsky nesmírně přívětivé ruční i on-line vyhodnocení TOMAL-2. Pozitivním aspektem podnětových materiálů je také to, že na rozdíl od Reyovy-Osterriethovy komplexní figury nebo Bentonova vizuálního retenčního testu nevyžadují zapojení grafomotorických schopností. Porucha percepčně motorické oblasti může totiž ovlivnit grafomotorické schopnosti a v důsledku i pamět'ový výkon v těchto dvou testech (Adams \& Reynolds, 2009). Dobře zpracován je také manuál k české verzi, který obsahuje minimum terminologických nesrovnalostí či překlepů.

\subsection{Závěry:}


Celkově TOMAL-2 představuje kvalitní nástroj pro posouzení paměti. Psychometrické zpracování české adaptace je vysoce nadprůměrné a př́kladné. Přímý konkurent TOMAL-2 na českém trhu, Wechslerova pamětová škála WMS-III, disponuje pouze americkými, a navíc zastaralými normami (Wechlser, 1999). Její kratší verze, Wechslerova zkrácená pamět'ová škála WMS-IIIa (2011), sice české normy má, ale jejich kvalita je bohužel nízká (podrobněji viz Hlavová \& Rosická, 2018). WMS-IIIa navíc představuje spíše screeningový nástroj, který nemůže nahradit komplexnější vyšetření paměti (Mitrushina a kol., 2005). Česká adaptace Wechslerovy pamět'ové škály WMS-IV, která je revizí WMSIII a řeší řadu jejích omezení (viz Groth-Marnat \& Wright, 2016), se momentálně nepřipravuje (S. Ježek, osobní komunikace, 14. ř́jna 2019). Domnívám se, že TOMAL-2 lze doporučit jako momentálně nejkvalitnější test paměti na českém trhu, a to pro použití v oblasti neuropsychologie a v oblastech klinické, školní a poradenské psychologie.

\subsection{Doporučení (vyberte jedno)}

Všechny následující charakteristiky uvedené níže by měly mít ratingy [n/a], [2], [4], [5], pokud by měl být nástroj „doporučen“ pro obecné použití (hodnocení 5 nebo 6):

[2.9] Normy a referenční skupiny

[2.10.1] Konstruktová validita

[2.10.2] Kriteriální validita

[2.11] Reliabilita - celková

[2.12] Počítačově generované

zprávy

Pokud má kterýkoli z výše uvedených ratingů hodnotu [] nebo [1], nástroj by měl být klasifikován pod doporučením 1, 2, 3 nebo 4, nebo klasifikován pod doporučením 7 “jiné" s adekvátním vysvětlením.
1 Pouze výzkumný nástroj. Ne pro užití v praxi.

2 Vhodný pouze pro užití expertním uživatelem za pečlivě kontrolovaných podmínek nebo ve velmi omezených aplikačních oblastech

3 Vhodný pro použití pod supervizí $\mathrm{v}$ aplikační(ch) oblasti(ech) definovaných distributorem, libovolnými uživateli $\mathrm{s}$ obecnými kompetencemi pro používání a administraci testů

4 Vyžaduje další vývoj. Vhodný pouze pro použití ve výzkumu.

凶 5 Vhodný pro používání $\mathrm{v}$ aplikační(ch) oblasti(ech) definovaných distributorem, uživateli testů, kteří splňují speciální kvalifikační požadavky distributora

6 Vhodný pro sebevyšetření bez supervise $\mathrm{v}$ aplikační(ch) oblasti(ech) definovaných distributorem

7 Jiné:

\section{Odkazy k poznámkám a bibliografie}

Adams, W., \& Reynolds, C. R. (2009). Essentials of WRAML2 and TOMAL-2 Assessment. John Wiley \& Sons.

Česká školní inspekce. (2014). Sekundární analýzy výsledků šetření PISA 2012. https://www.csicr.cz/Csicr/media/Prilohy/PDF el. publikace/Mezin\%C3\%A1rodn\%C3\%A D\%20\%C5\%A1et\%C5\%99en\%C3\%AD/PISA 2012 SA.pdf

Dehn, M. J. (2010). Long-term memory problems in children and adolescents: Assessment, intervention, and effective instruction. John Wiley \& Sons.

Drozdick, L. W., Holdnack, J. A., \& Hilsabeck, R. C. (2011). Essentials of WMS-IV Assessment. John Wiley \& Sons.

Groth-Marnat, G., \& Wright, J. A. (2016). Handbook of psychological assessment (6th ed.). John Wiley \& Sons. 
Hartman, D. (2007). TEST REVIEW: PSST! Wanna buy a good new memory test-cheap?: The Test of Memory and Learning-2. Applied Neuropsychology, 14(4), 307-309. https://doi.org/10.1080/09084280701719443

Hlavová, R., \& Rosická, A. M. (2018). Wechslerova zkrácená pamět’ová škála: Recenze metody. Testfórum, 11, 43-48. http://doi.org/10.5817/tf2018-11-203

Howes, N. L., Bigler, E. D., Lawson, J. S., \& Burlingame, G. M. (1999). Reading disability subtypes and the test of memory and learning. Archives of Clinical Neuropsychology: The Official Journal of The National Academy of Neuropsychologists, 14(3), 317-339.

http://search.ebscohost.com/login.aspx?direct=true \&db=mdc\&AN=14590599\&lang=cS

Iliescu, D. (2017). Adapting tests in linguistic and cultural situations. Cambridge University Press. Katedra psychologie FSS. (2019). Nabídka práce: Standardizace Testů školních dovedností (BACH). https://psych.fss.muni.cz/cosedeje/aktuality/nabidka-prace-standardizace-testu-skolnichdovednosti-bach

Lowther, J. L., \& Mayfield, J. (2004). Memory functioning in children with traumatic brain injuries: a TOMAL validity study. Archives of Clinical Neuropsychology: The Official Journal of The National Academy of Neuropsychologists, 19(1), 105-118.

http://search.ebscohost.com/login.aspx?direct=true\&db=mdc\&AN=14670383\&lang=cS

McCallum, R. S. (2003). Handbook of Nonverbal Assessment. Springer Science \& Business Media.

Mitrushina, M., Boone, K. B., Razani, J., \& D'Elia, L. F. (2005). Handbook of normative data for neuropsychological assessment. Oxford University Press.

Propsyco. (2017). Test paměti a učení - Druhé vydání: Příručka. Propsyco, s.r.o.

Propsyco. (2019). Propsyco. https://shop.propsyco.cz/

Reynolds, C. R., \& Bigler, E. (1994). Test of Memory and Learning. PRO-ED.

Reynolds, C. R., \& Voress, J. K. (2007). Test of Memory and Learning: Second Edition. PRO-ED.

Reynolds, C. R., \& Voress, J. K. (2012). TOMAL-SE: Test of memory and learning-senior edition. PRO-ED.

Sheslow, D., \& Adams, W. (2003). Wide Range Assessment of Memory and Learning-Second Edition. Wide Range.

Schmitt, A. J., \& Decker, S. L. (2008). Review of Test of memory and learning: Second edition. Journal of Psychoeducational Assessment, 27(2), 157-166. https://doi.org/10.1177/0734282908322449

Thaler, N. S., Allen, D. N., McMurray, J. C., \& Mayfield, J. (2010). Sensitivity of the Test of Memory and Learning to attention and memory deficits in children with ADHD. The Clinical Neuropsychologist, 24(2), 246-264. https://doi.org/10.1080/13854040903277305

Thaler, N., Barney, S., Reynolds, C., Mayfield, J., \& Allen, D. (2011). Differential sensitivity of TOMAL subtests and index scores to pediatric traumatic brain injury. Applied Neuropsychology, 18(3), 168-178. https://doi.org/10.1080/13854040903277305

Wechsler, D. (1999). Wechslerova pamět’ová škála WMS-III. Psychodiagnostika.

Wechsler, D. (2011). Wechslerova zkrácená pamětová škála WMS-IIIa. Hogrefe - Testcentrum. 
Měřené konstrukty:

Verbální pamět', neverbální pamět', celková pamět', bezprostřední pamět', oddálené vybavení, pozornost a soustředění, učení, prostorová pamět', sekvenční pamět'. 